\title{
Do exogenous changes in passive institutional ownership affect corporate governance and firm value?
}

\author{
Cornelius Schmidt and Rüdiger Fahlenbrach*
}

First Draft: May 25, 2012

This Draft: June 30, 2016

\begin{abstract}
We investigate whether corporations and their executives react to an exogenous change in passive institutional ownership and alter their corporate governance structure. We find that exogenous increases in passive ownership lead to increases in CEO power and fewer new independent director appointments. Consistent with these changes not being beneficial for shareholders, we observe negative announcement returns to the appointments of new independent directors. We also show that firms carry out worse mergers and acquisitions after exogenous increases in passive ownership. These results suggest that the changed ownership structure causes higher agency costs.
\end{abstract}

Keywords: Corporate Governance; Institutional Ownership; Monitoring; Index Reconstitutions

JEL Classification: G34, G23, G32

* Schmidt is Adjunct Associate Professor at the Department of Finance, Norwegian School of Economics (NHH), 5045 Bergen, Norway and is with the European Commission (DG Competition - Chief Economist Team). Fahlenbrach is Associate Professor at the Swiss Finance Institute, Ecole Polytechnique Fédérale de Lausanne (EPFL), Quartier UNILDorigny, Extranef 211, CH-1015 Lausanne. The paper is derived from the first chapter of Schmidt's 2013 dissertation at the University of Lausanne and was previously circulated under the title "Shareholder Monitoring Incentives and Corporate Policies". We thank Eliezer Fich (the referee) whose comments have significantly improved the paper. Bo Becker, Carsten Bienz, Alon Brav, Itzhak Ben-David, Pierre Collin-Dufresne, Espen Eckbo, Isil Erel, Amit Goyal, Yaniv Grinstein, Christoph Herpfer, Michael Ingenhaag, Victoria Ivashina, André Lucas, Loriano Mancini, Roni Michaely, Bernadette Minton, Konrad Raff, Norman Schürhoff, Laura Starks, René Stulz, Karin Thorburn and Michael Weisbach as well as seminar participants at the Ohio State University, the 2012 Swiss Finance Institute Doctoral Workshop in Gerzensee, EPFL, NHH Bergen, Warwick Business School, BI Oslo, VU Amsterdam and the University of Bern provided helpful comments and suggestions. Claire Eagle from Russell Investments provided precious feedback on the construction of the index data. We thank Brian Bushee for sharing his investor classification data and Antti Petajisto for sharing his benchmark classification data. Karl Fredrik Schjøtt-Pedersen provided excellent research assistance.

Fahlenbrach and Schmidt gratefully acknowledge financial support from the Swiss Finance Institute. Schmidt gratefully acknowledges financial support from the Swiss National Science Foundation and NHH's FOCUS initiative. Part of this research was completed while Schmidt was a visiting scholar at The Ohio State University. The views expressed in this article are personal, and do not necessarily represent those of DG Competition or of the European Commission. Schmidt is corresponding author (e-mail: cornelius.schmidt@nhh.no).

(C) 2017. This manuscript version is made available under the Elsevier user license

http://www.elsevier.com/open-access/userlicense/1.0/ 


\section{Introduction}

From 2007 through 2013, U.S. index domestic equity mutual funds and exchange-traded funds (ETFs) received $\$ 795$ billion in cumulative net new cash and reinvested dividends, and at the end of 2013, index mutual funds and large cap ETFs held $\$ 1.2$ trillion and $\$ 450$ billion in assets, respectively. Actively managed domestic equity mutual funds had outflows of $\$ 575$ billion (Investment Company Institute, 2014). The dramatic increase in ownership of U.S. corporations by passively managed funds raises important issues for the corporate governance of firms because it is uncertain to what extent passively managed funds have the capacity and interest to monitor corporations.

The academic governance literature proposes two main channels through which large institutional investors can affect corporate governance decisions: Voice and exit (the "Wall Street walk"). Both channels, however, appear ill-suited for index-tracking institutions. The voice channel, in which institutional investors actively interact with management to voice their preferences, seems expensive for low-cost and low-overhead passive institutional investors that cover thousands of stocks. The exit channel is not available to institutional investors who track indexes and are often paid by tracking error. Passive institutional investors insist that they have a fiduciary duty to exercise governance and do so, for example, through informal meetings with management and through voting at annual general meetings. It is not clear, however, how active they really are in corporate governance. Organizations such as Institutional Shareholder Services (ISS) that give vote recommendations to institutional investors at annual general meetings have rapidly grown and there exists evidence that many institutional investors mechanically follow their advice so that they can prove to have complied with their fiduciary duties (Malenko and Shen, 2016).

In this paper, we ask whether the increase in passively managed institutional ownership changes the governance of corporations to the detriment of shareholders, or whether index-tracking institutions participate in governance as much as more active institutions. If corporate governance worsens, do managers take advantage of a change in their firm's shareholder structure towards more passive ownership to advance their personal interests? 
We concentrate on two corporate governance areas which executives may rapidly influence after a change in the balance of power in corporations - the board of directors and their relative power in the organization measured by an accumulation of titles (e.g., Morck, Shleifer, and Vishny, 1989). We also examine whether passive institutional investors use their main governance device, shareholder proposals, more actively. We study announcement returns to mergers and acquisitions to test whether agency costs are higher and whether managers can reap personal gains from empire building after increases in passive ownership.

One challenge for our analysis is the endogenous nature of a company's shareholder structure. It is plausible to expect that a firm's shareholder structure is influenced by firm characteristics that also drive changes in governance. For example, Brav et al. (2008) find that hedge fund activists target firms that have a low market value relative to book value, low payout ratios, more takeover defenses, and high chief executive officer (CEO) pay. One of the contributions of our paper is therefore to use-in addition to the standard ordinary least squares (OLS) approach-plausibly exogenous changes in a firm's shareholder structure. The exogenous change is driven by the annual reconstitution of the Russell 1000 and the Russell 2000 indexes, following Chang, Hong, and Liskovich (2015). The reconstitution of the indexes changes the shareholder structure because the Russell 1000 index (the largest 1,000 U.S. stocks by market capitalization) and the Russell 2000 index (the $1,001^{\text {st }}$ to $3,000^{\text {th }}$ largest U.S. stocks by market capitalization) are value-weighted. A stock moving from the bottom in the Russell 1000 index to the top of the Russell 2000 index will become much more important to an index-tracking institution.

Using a sample of U.S. stocks from 1993-2010, we find evidence suggesting that corporate executives use the (index-reconstitution-driven) exogenous change in the shareholder base to influence corporate governance to advance their personal interests. We find that the power of CEOs increases in firms with more passive owners. The likelihood to become chairman or president increases significantly. While the fraction of independent board members does not change, we find that in firms with more passive investors, independent board turnover decreases so that directors serve longer terms. Interestingly, the incidence of a broad basket of governance-related shareholder proposals does not change following changes in the shareholder base, which is 
consistent with these shareholder proposals not being initiated by the passive, index-tracking institutional shareholders that form the basis of our study.

Are the observed changes in governance good or bad for shareholders? The answer is not obvious. For example, more powerful CEOs may be able to have more influence on the firm and help the firm succeed (e.g., Adams, Almeida, and Ferreira, 2005, 2009; Anderson and Reeb, 2003; Fahlenbrach, 2009) but are also more entrenched and may be able to carry out actions that are to their personal benefit but to the detriment of shareholders. To answer this question, we examine the announcement returns to two governance changes -the accumulation of titles and new director appointments. ${ }^{1}$ We find evidence that shareholders react more negatively to the accumulation of titles and the appointment of new directors in firms with more passive owners, consistent with these governance changes being value-decreasing.

Finally, we examine whether firms undertake more value-decreasing mergers and acquisitions (M\&A), after exogenous increases in passive ownership. Jensen (1986) emphasizes that value-destroying M\&A activity is one of the main mechanisms for extracting private benefits in public corporations. Masulis, Wang, and Xie (2007) empirically show that managers of firms with less effective corporate governance indeed engage in more value-destroying acquisitions. We find strong evidence that the cumulative announcement returns to mergers and acquisitions decrease after exogenous increases in passive ownership and that the reduction of shareholder value is economically meaningful in dollar terms. In additional tests, we show that the same firms make worse M\&A decisions after they experience an exogenous increase in passive ownership.

Our paper's hypotheses are firmly grounded in existing theory and relate to several strands of the empirical literature on institutional ownership and governance that we review in Section 2. A few papers use an identification strategy similar to ours. Chang, Hong, and Liskovich (2015) recognize that index reassignments of the Russell indexes provide an exogenous variation in ownership. They examine asset pricing implications, such as price pressure and asset correlations. Using the same identification strategy,

1 We take great care to only examine announcements of director appointments and accumulation of titles that are communicated on days without confounding news. 
Crane, Michenaud, and Weston (2016) focus on payout policy and show that exogenous increases in institutional ownership lead to higher payouts. Fich, Harford, and Tran (2015) analyze acquisition outcomes, Boone and White (2015) analyze firm transparency, and Mullins (2014) analyzes executive compensation.

The closest paper to ours is the article by Appel, Gormley, and Keim (2016). They also analyze how passive investors impact corporate governance and employ the Russell index reconstitution to establish causality. Appel, Gormley, and Keim (2016) examine basic corporate governance characteristics such as removal of poison pills, establishment of equal voting rights, or an increase in board independence. They choose these characteristics because the largest passive institutional investors themselves describe them as important in public speeches or publications. Appel, Gormley, and Keim (2016) argue that these characteristics are targeted because they require a relatively low level of costly monitoring. They find that several governance mechanisms improve with more passive ownership and that voting behavior at annual general meetings changes. While they do not find improvements in firm performance for their overall sample, they provide some evidence of better long-term accounting performance in subsets of their sample. Overall, Appel, Gormley, and Keim (2016) therefore draw conclusions that appear more positive with respect to the role of passive institutional investors than ours.

We believe that the results of Appel, Gormley, and Keim (2016) and our results are not inconsistent with each other. Much of our evidence on value-reducing actions of managers after increases in passive ownership comes from an analysis of announcement returns to board appointments and mergers and acquisitions which are much more costly to monitor for passive institutions than the basic corporate governance characteristics that Appel, Gormley, and Keim (2016) study. Hence, it could be that the role of passive institutional investors for corporate governance is more complex than originally thought. More passive ownership affects corporate governance positively when it comes to low-cost governance activities such as consistently voting according to a pre-defined program at annual meetings or endorsing removal of poison pills and staggered boards. However, more passive ownership affects corporate governance negatively and reduces shareholder value when it comes to high-cost governance activities such as monitoring of mergers and 
acquisitions, the choice of board members, or the accumulation of titles that often happen outside of annual general meetings and require continuous monitoring.

Differences in methodology and analyzed outcome variables may help explain the difference in our and their findings on board independence. First, Appel, Gormley, and Keim (2016) use the membership in the Russell 2000 as an instrument for passive institutional ownership, while we employ the actual index switching firms as a source of variation in passive institutional ownership. Second, in our empirical setting we do not condition on Russell's float-adjusted market capitalization. Third, Appel, Gormley, and Keim (2016) define passive institutional investors as all index-tracking mutual funds including those that track non-Russell indexes such as the Standard and Poor's 500 (S\&P 500), while we focus on all funds and ETFs which have the Russell 1000 or 2000 as their primary benchmark and are thus affected by the index reconstitution. ${ }^{2}$ These methodological differences could explain the different findings with respect to board independence. ${ }^{3}$

The remainder of the paper is structured as follows. Section 2 reviews the theoretical and empirical literature on the monitoring incentives of institutional investors and derives testable hypotheses. Section 3 contains a description of the sample. Section 4 outlines our empirical approach and presents the results on changes in corporate governance, shareholder reactions to these changes, and our analysis of mergers and acquisitions. Section 5 shows robustness tests, and Section 6 concludes. Appendix A describes the construction of the Russell indexes, the validity of our instrumental variables and details on the calculation of the market capitalization. Appendix B contains a description of how we collect the announcement dates for director appointments and CEOs gaining and losing titles.

\section{Literature review and empirical predictions}

2 The correlation between their and our measure for passive ownership is 0.30 . Our passive ownership fraction is higher, approximately 6\% instead of 3\% in Appel, Gormley, and Keim (2016), and our jump in passive ownership around the index threshold is double their jump.

$3 \quad$ Crane, Michenaud, and Weston (2016) extensively discuss the different methodologies that have been used in the emerging literature on using index-reconstitution-driven changes in institutional ownership for identification. 
There is a large theoretical literature on concentrated ownership and monitoring by institutional investors focusing on the two channels voice (activist intervention) and exit. ${ }^{4}$ Theories of activist intervention generally model a free-rider problem. An activist fully bears the cost of intervention but shares the benefits of intervention with other shareholders. Theoretical work shows that institutional investors need to own a significant fraction of shares to overcome the free-rider problem (e.g., Shleifer and Vishny, 1986). Institutional investors as a group hold in excess of $60 \%$ of equity of large U.S. corporations, but it is rare that a single institutional investor holds more than $10 \%$ of equity in a single firm. Edmans and Manso (2011) show that a block held by multiple investors weakens the intervention channel because it creates a new free-rider problem. Hence, both models suggest that the voice channel is not an effective governance mechanism for the welldiversified passive institutional investors that are the subject of our study, although they may collectively hold a large stake in any given firm.

Admati and Pfleiderer (2009) and Edmans (2009) show that large shareholders can also exert governance through an alternative channel, the credible threat of exit. Edmans and Manso (2011) show that splitting a block among multiple shareholders can potentially enhance the exit channel if agency problems are severe. We examine the ownership changes of passive institutional investors who are often being paid by tracking error. Such a compensation scheme makes the exit channel unattractive and less credible because deviations from the index return caused by excluding too many firms are privately costly to fund managers.

Recent theoretical papers integrate both the voice and exit mechanisms of institutional investor governance (e.g., Levit, 2014; Dasgupta and Piacentino, 2015). Levit (2014) shows that the threat of exit improves the effectiveness of the voice mechanism. Dasgupta and Piacentino (2015) show that when mutual fund managers compete for investor capital, their threat of exiting investments loses its credibility, and also weakens the voice channel. Given that most of the passive institutional investors in our sample belong to large mutual fund families, the predictions of the Levit (2014) and Dasgupta and Piacentino (2015) models suggest that passive index investors have a disadvantage in monitoring relative to more active investors.

$4 \quad$ See Edmans (2014) for an excellent survey of the theoretical literature. 
Our work is also related to the empirical academic literature on the monitoring capacities of institutional investors. Several papers caution about the monitoring abilities and incentives of passive institutional investors, citing a variety of issues. Roe (1990) describes the regulatory constraints imposed on many mutual funds and pension funds that could prevent them from buying large stakes and monitoring. Large passive institutional investors are potentially concerned about losing money management business (e.g., Brickley, Lease, and Smith, 1988; Davis and Kim, 2007), and delegated portfolio management at the largest institutional investors introduces agency problems of its own (e.g., Diamond, 1984; Woidtke, 2002). If the above papers are right about the monitoring attitude of some passive institutional investors, we predict that an increase of passive ownership leads to negative shareholder value consequences. We test this prediction using M\&A transactions.

There is also a more positive view on the monitoring capabilities of institutional investors once investor heterogeneity has been taken into account. Broadly speaking, institutional investor monitoring becomes more important if the institution's holdings are more undiversified, if they hold large blocks, and if they have board or management representation. Aghion, Van Reenen, and Zingales (2013) find that firms with more active institutional investors invest more in corporate innovation, while there is no such association for firms with more passive investors. Fich, Harford, and Tran (2015) show that institutional investors with an important stake in firms targeted in M\&A deals positively influence acquisition completion rates and target deal premiums. Cronqvist and Fahlenbrach (2009) explicitly take institutional investor heterogeneity into account and show that the institutions with the most impact are active investors with larger stakes and board representation. Brav et al. (2008) show that hedge fund activists have an impact on corporate policies and governance. Bertrand and Mullainathan (2001) find that CEOs are rewarded for luck in their compensation except in instances of oversight by a large shareholder. Hartzell and Starks (2003) find that increased monitoring, measured by institutional ownership concentration, is associated with a higher fraction of a CEO's salary that is paid in equity.

Based on the above theoretical and empirical papers we explore whether an exogenous shock that increases the ownership of passive institutional investors may lead to a decrease in monitoring or to an 
increase in $\mathrm{CEO}$ power and entrenchment. We therefore predict that the exogenous increase in passive institutional investors is associated with a board of directors that is friendlier towards the CEO. We follow the approach of Shivdasani and Yermack (1999) and examine the appointment of new independent directors. Shivdasani and Yermack (1999) show that if the CEO is powerful or a member of the nominating committee, less new independent directors get appointed. Conditionally on appointing a new independent director, the announcement return is negative if the CEO is involved in the selection process. Applied to our setting, we expect director appointments in firms with more passive institutional investors to be associated with poorer announcement returns because it is more likely that the CEO interfered with the candidate choice.

Our main measure of CEO power is the accumulation of titles as in Morck, Shleifer, and Vishny (1989), Adams, Almeida, and Ferreira (2005), and Morse, Nanda, and Seru (2011). If the CEO is also president of the company or chairman of the board of directors, his influence increases. If she is the chairman, she can direct board initiatives, whereas serving also as a president makes her more difficult to be replaced as CEO since there is no president available who can succeed her (Naveen, 2006). We also predict that increases in CEO power after reductions in institutional investor monitoring are detrimental to shareholders because CEOs become more entrenched. Existing empirical evidence, although examining different outcome variables, suggests that this is the case. Morck, Shleifer, and Vishny (1989) show that board-induced CEO turnover is less likely when the CEO has accumulated more titles. Similarly, Morse, Nanda, and Seru (2011) show how CEOs use their power to manipulate incentive contracts and generate private benefits. We predict that the announcement returns to news that CEO power increases are lower if they occur after increases in passive institutional ownership.

There is some evidence that passive and well-diversified institutional investors, in particular pension funds, get involved in firm governance through shareholder proposals and informal discussions. McCahery, Sautner, and Starks (2016) provide survey evidence that institutional investors privately talk to portfolio firms and, whenever their investment strategy allows, use governance-motivated exits. But their survey also shows that institutional investors generally rely on proxy advisors' vote recommendations. Carleton, Nelson, and Weisbach (1998) show that active, private negotiations between TIAA-CREF and their portfolio firms exist on 
governance issues and that TIAA-CREF are typically successful in obtaining their objectives. However, they also show that TIAA-CREF focus on a small number of proxy-related topics and typically target the largest firm in a given industry, likely because of resource constraints. Del Guercio and Hawkins (1999) show that pension fund shareholder proposals have a significant impact on company policies, especially those by CalPERS and CalSTRS. Yet, Gillan and Starks (2007) come to the conclusion that there is little evidence of improvements in performance of firms targeted by well-diversified pension funds.

Based on the above papers that show an impact of mainly more active pension funds on the number of shareholder proposals and their success of passing, we predict that the incidence of shareholder proposals does not change when passive, index-tracking institutional ownership increases.

\section{Data and summary statistics}

We obtain data from Russell Investments, Thomson Reuters, Compustat ExecuComp, Compustat Annual, the Center for Research in Security Prices (CRSP), RiskMetrics/Investor Responsibility Research Center (IRRC), SDC Platinum, and electronic SEC filings (8-K).

\subsection{Sample construction}

The starting point of our sample is data on index constituents for the Russell 1000 and Russell 2000 indexes provided by Russell Investments from 1992 to 2010. Russell Investments ranks all U.S. stocks according to their raw market capitalization by the end of May each year using a proprietary measure. The raw market capitalization ranking also takes into account shares that are not part of a firm's free-float [for details on the methodology, see our Appendix A; Chang, Hong, and Liskovich (2015); Russell Investments (2011)]. The largest 1,000 firms by raw market capitalization are members of the Russell 1000 index, whereas the Russell 2000 index consists of firms with a rank based on raw market capitalization between 1,001 and 3,000. ${ }^{5}$ Index reconstitution takes place once a year. We match these 3,000 stocks each year by CUSIP to CRSP,

$5 \quad$ Starting with its 2007 reconstitution, Russell initiated a banding policy around the 1,000 cut-off to reduce index turnover. If an index member's market capitalization did not deviate much from the threshold, it remained in its original index (see Russell Investments, 2011; Chang, Hong, and Liskovich, 2015 for details). 
Compustat, and a mutual fund holdings data set (Thomson Reuters s12) to obtain stock market, accounting, and institutional investor holding data.

We aggregate the ownership of all mutual funds and exchange traded funds whose primary Morningstar Benchmark is one of the Russell 1000 or Russell 2000 indexes (total return, value, or growth). ${ }^{6}$ These are the passive institutional owners who should be most affected by the Russell 1000 and Russell 2000 index reconstitution and who drive the previously documented changes in ownership at the reconstitution threshold. We match these passive institutional investors by fund manager number to the Thomson Reuters s12 data on stockholdings of mutual funds, and add the holdings by Russell 1000/2000 exchange traded funds by hand. ${ }^{7}$ In the remainder of the paper, we refer to the ownership of these Russell index-tracking institutions as passive institutional ownership.

One could also have used the quasi-index tracking institutional investor category of Bushee (2001) to identify passive institutional investors. Bushee (2001) distinguishes between transient institutions that have high portfolio turnover and diversified portfolios, dedicated institutions that have low turnover and more concentrated portfolio holdings, and quasi-indexing institutions that have low turnover and diversified portfolio holdings. Our approach has three advantages. We look at the self-declared benchmark of individual funds and thus we identify mutual funds and ETFs that are affected by the index reconstitution in a clean way. Second, one potential limitation of Bushee's (2001) classification is that it is based on Thomson 13f data which aggregate data at the fund family / institution level. The aggregation adds noise to a measure that seeks to track only a subset of funds. For example, the Thomson Financial $13 \mathrm{f}$ data have one entry for Fidelity Management and Research, which aggregates holdings across thousands of different funds. While Bushee's classification would identify Fidelity as a quasi-indexer, only a subset of its funds tracks the Russell indexes and is affected by the index reconstitution. Third, there are some misclassifications of active institutional investors as quasi-indexers (QIX). For example, TIAA-CREF and CalPERS are considered QIX investors in Bushee's classification, but Carleton, Nelson, Weisbach (1998) and Del Guercio and Hawkins (1999)

$6 \quad$ We use the benchmark classification provided by Petajisto (2013). His data are available until December 2009. To make use of our complete sample, we use the mutual fund benchmark information from 2009 also for 2010.

7 In particular, these are the Russell 1000/2000 ETFs of the Ishares family. 
convincingly show that they are quite active in governance. The drawback of our approach is that the level of passive institutional ownership is lower relative to those papers that use Bushee's (2001) classification.

However, identification in all papers that use the same experiment does come from the set of funds we identify and the percentage changes in passive ownership are comparable across papers. Overall, we believe that our approach offers advantages. We nevertheless discuss in the robustness section how our results change if we use the Thomson 13f data and a modified Bushee (2001) classification that removes more active owners instead.

Board of director and shareholder proposals data are from RiskMetrics/IRRC. We follow Cuñat, Gine, and Guadalupe (2012) and analyze shareholder proposals that change any of the governance provisions of the G-index of Gompers, Ishii, and Metrick (2003) to make overall governance more shareholder-friendly.

M\&A announcement dates as well as M\&A deal characteristics are from SDC Platinum. The sample selection criteria are similar to Moeller, Schlingemann, and Stulz (2005). We include in our sample all completed deals in which the acquirer controls less than $50 \%$ of the shares of the target at the announcement date and obtains $100 \%$ of the target shares. In addition, the deal value has to be equal to or greater than $\$ 1$ million and represent at least $1 \%$ of the acquirer's market capitalization, the target has to be a public firm, private firm, or subsidiary, and the deal has to be successfully completed in less than 1,000 days and we exclude withdrawn deals. We do not include withdrawn deals in our analysis because we cannot determine whether the acquiring firm made an attempt to increase its shareholdings from (less than) $50 \%$ to $100 \%$ or, for example, from $25 \%$ to $75 \%$. Moreover, by focusing only on completed transactions we do not rely on the market's expectation that the deal will be completed (Masulis, Wang, and Xie, 2007). We also exclude deals with estimated announcement dates.

Data on appointments as president or CEO as well as independent director appointment dates are collected from 8-K filings electronically available at the SEC, taking care to remove announcements that happen concurrently with confounding events (e.g., merger announcements). Appendix B provides details on the procedure used to obtain those announcements. Table 1 contains definitions of all variables and indicates the respective source of data. 


\subsection{Summary statistics}

Table 2 provides summary statistics for key variables. We winsorize all variables at the $1^{\text {st }}$ and the $99^{\text {th }}$ percentiles. The mean (median) market capitalization of sample firms is $\$ 3,093$ million ( $\$ 665$ million), and the mean index weight for each stock is $0.06 \%$. Passive institutional investors hold on average $5.5 \%$ of the shares of sample firms. The mean (median) change in passive institutional investors is $0.28 \%(0.23 \%)$. The CEO is also chairman of the board in 58.3\% of firm-year observations, and president in $53.7 \%$ of all firm-year observations. ${ }^{8}$ The average annual change in the chairman and president position is $2 \%$ and $2.7 \%$, respectively.

The board of directors consists of $67.7 \%(71.4 \%)$ independent directors for the average (median) firmyear. These statistics are very close to those reported in other recent board studies. Masulis and Mobbs (2014), for example, report an average (median) of $66.2 \%$ (69.2\%) of independent directors. Board independence is on average increasing by $1.6 \%$ during our sample period, which is similar to numbers provided in earlier studies (e.g., Linck, Netter, and Yang, 2008). During the average firm-year, a firm adds 0.78 new independent directors to its board, which conditional on board size, corresponds to an independent board turnover of $8 \%$. $^{9}$ Finally, in $6.5 \%$ of all firm-years, shareholders add a G-index-related shareholder proposal to the agenda of the annual general meeting, which is close to the incidence reported by Cuñat, Gine, and Guadalupe (2012).

The merger and acquisition deal characteristics of our sample are as follows: $25 \%$ of all targets are publicly listed firms, $42 \%$ are private firms, and the remaining are subsidiaries. $26.5 \%$ of deal consideration is paid in shares, $0.3 \%$ of all sample deals are hostile, and in $1.0 \%$ of all deals, there are multiple competing bids. The average ratio of the deal value to acquirer market value is $18 \%$, and in approximately $60 \%$ of deals acquirer and target share the same first two digits of their primary SIC codes. These statistics are very close in magnitude to those reported by Moeller, Schlingemann, and Stulz (2005) for a large sample of deals between 1980 and 1997.

8 Linck, Netter, and Yang (2008) find for their sample that the CEO is chairman of the board in 58.3\% of all firmyear observations.

Fahlenbrach, Low, and Stulz (2014) find an unconditional probability of outside director turnover of $7.5 \%$, which is very close to the $8 \%$ we report. 
Our sample contains 144 announcements of the CEO also obtaining the chairman or president position. The average and median announcement returns are close to zero. We are able to obtain announcement dates for 1,991 new independent director appointments. The average (median) Fama French four-factor cumulative independent director announcement returns are $0.349 \%(0.129 \%)$. This CAR is estimated during the four-day window $[-4,0]$, in which day " 0 " equals the filing date of Form 8-K. The Form 8-K has to be filed within two business days with an automatic extension of two business days.

There are 9,125 mergers and acquisitions between 1993 and 2010 that satisfy our sample selection criteria. The average Fama French four-factor cumulative abnormal return to mergers and acquisitions of sample firms is $0.369 \%$ and the median cumulative abnormal return is $0.161 \%$. The CAR is estimated during the window $[0,1]$, with day "0" being the merger announcement date. The CARs are comparable in magnitude to those reported by Masulis, Wang, and Xie (2007). They estimate an average CAR of $0.215 \%$ and a median CAR of $0.105 \%$ for a large sample of M\&A deals announced between 1990 and 2003.

\section{Empirical methodology and results}

We briefly describe our identification strategy, followed by the results on changes in governance and the shareholder value implications of such governance changes.

\subsection{Empirical methodology}

We first analyze the effects of changes in passive institutional ownership on corporate governance in an OLS framework with first differences:

$$
\Delta y_{i t}=\alpha_{t}+\theta_{j}+b_{2} \Delta X_{i t}+c \Delta \text { Passive institutional investors } i t+\varepsilon_{i t},
$$

where $\Delta y_{i t}$ is the change in the governance variable, $\alpha_{t}$ indicate year-fixed effects, $\theta_{j}$ industry-fixed effects, $\Delta X_{i t}$ are changes in firm characteristics, and $\Delta$ Passive institutional investors are changes in the ownership of passive institutional investors. Using first differences removes any firm-specific time-invariant unobservable variable, but it cannot address other issues such as reverse causality or omitted time-varying variables. We 
therefore also develop an instrumental variable approach and estimate it in a standard two-stage least squares (2SLS) estimation framework. The first stage is a regression of changes in passive institutional investor ownership on a set of instruments:

$$
\begin{aligned}
& \Delta \text { Passive institutional investors } i t=\alpha_{t}+\theta_{j}+b \Delta X_{i t}+\beta_{1} I_{1000, i, t-1} \rightarrow I_{2000, i, t} \\
& \quad+\beta_{2} I_{2000, i, t-1} \rightarrow I_{1000, i, t}+\delta\left(\operatorname{rank}_{i, t}-\operatorname{rank}_{i, t-1}\right)+u_{i t},
\end{aligned}
$$

where $\alpha_{t}$ indicate year-fixed effects, $\theta_{j}$ are industry-fixed effects, and $\Delta X_{i t}$ are time-varying firm characteristics included in the second stage. Our instruments for passive institutional ownership are an indicator variable equal to one if a firm switches from the Russell 1000 to the Russell $2000, I_{1000, i, t-1} \rightarrow$ $I_{2000, i, t}$, an indicator variable equal to one if a firm switches from the Russell 2000 to the Russell 1000, $I_{2000, i, t-1} \rightarrow I_{1000, i, t}$, as well as the difference in ranks based on the raw market capitalization of the firm in year $t$ and year $t-1 .{ }^{10}$ Chang, Hong, and Liskovich (2015) show that the amount of money benchmarked to the Russell 1000 and Russell 2000 are approximately of the same order of magnitude. But since the indexes are value-weighted, the market-capitalization-based weights of the lowest ranked members of the Russell 1000 are approximately ten times smaller than the weights of the highest ranked members of the Russell 2000. Hence, Russell index-tracking institutions will significantly increase their holdings of firms that switch from the Russell 1000 to the Russell 2000 and decrease the holdings of firms that switch from the Russell 2000 to the Russell 1000. At the index threshold, the differences in market capitalizations are minimal, and there are no other criteria by which index inclusion is determined. Index assignment of firms close to the threshold is basically random, and we exploit the exogenous variation in passive institutional ownership stemming from changing the index for identification. ${ }^{11}$ Fig. 1 plots the ownership of Russell 1000 and Russell 2000 indextracking institutions against the rank implied by raw market capitalization. Fig. 1 shows a clear jump in the

10 Fich, Harford, and Tran (2015) follow a similar instrumental variable approach that is based on index switching firms and rank changes to examine the impact of active institutional investors.

11 A potential concern for firms which experience a large change in market capitalization and switch the index is that such change is related to some unobservable component of poor corporate governance, which would violate the exclusion restriction. We control explicitly for changes in market capitalization and the initial market capitalization in all regressions to mitigate this concern. In addition, we employ additional tests in the robustness section where we reestimate the main regressions on a sample with only small changes in market capitalization. 
ownership of passive Russell tracking institutional investors around the market capitalization threshold (rank 1000) that determines whether a firm belongs to the Russell 1000 or Russell 2000. The jump is in the predicted direction: Firms just above the threshold have a significantly higher ownership by passive institutional investors. Table 3 confirms the results of Fig. 1 in a regression framework.

Table 3 shows that the relevancy condition holds, using regression results of a change in passive institutional investors on our instrumental variables. Column 1 presents results for the entire sample period, Column 2 shows results from 2004 - 2010 (some of our tests are, because of data availability, restricted to this subperiod), and Column 3 shows results for the entire sample period, but with a restriction on firm-years with available governance data. Column 3 also includes a set of typical control variables we will use later on. All three columns show that the instruments are relevant and work in the predicted direction. If a stock moves from the Russell 1000 to the Russell 2000 index, index-tracking institutions increase their ownership. If a stock moves from the Russell 2000 index to the Russell 1000 index, index-tracking institutions decrease their ownership. As a firm moves up in the market capitalization ranking and thus $\left(\operatorname{rank}_{i, t}-\operatorname{rank}_{i, t-1}\right)$ is negative, firms attract more passive institutional investors within an index since larger stocks allow them to more accurately track the index performance. The coefficient on market capitalization in the prior year is negative, which shows that controlling for the change in rank, smaller firms experience larger increases in passive ownership. In these regressions, we exclude firm-year observations if the firm got newly added to the Russell 1000 or the Russell 2000 index, but was before in no Russell index. We impose this restriction because most of our governance databases include only S\&P 1500 index firms.

We then estimate in the second stage a regression of the change in the outcome variable $\Delta y_{i t}$ on changes in firm characteristics $\Delta X_{i t}$ and the predicted change in passive institutional ownership from Eq. (2):

$$
\Delta y_{i t}=\alpha_{t}+\theta_{j}+b_{2} \Delta X_{i t}+\gamma \Delta \text { Passive institutional investors }{ }_{l t}+\varepsilon_{l t}
$$

The coefficient of interest is $\gamma$ which measures the effect of instrumented changes in passive institutional ownership on changes in corporate policies. We provide a more detailed description of the instruments in Appendix A. 


\subsection{Empirical analyses}

We first show three sets of results that examine how changes in passive institutional ownership are related to changes in CEO power, the composition of the board of directors, and shareholder proposals. In a second step, we examine the market reactions to director appointments and announcements of cumulation of titles to document that the corporate governance changes affect firm value. In addition, we show how M\&A deal characteristics are affected and how M\&A announcement returns depend on passive institutional ownership.

\subsubsection{CEO power}

Table 4 shows the results of OLS and instrumental variable (IV) regressions of the change in whether the CEO is also chairman or president on changes in passive institutional ownership and firm characteristics. Columns 1 and 3 show the baseline OLS results. The baseline results indicate that an increase in passive institutional ownership is positively associated with an increase in the likelihood that the CEO becomes president, and unrelated to the likelihood that the CEO also becomes chairman of the board. CEOs are more likely to be appointed chairman if past and concurrent performance is good, and if assets grow significantly. CEOs at smaller firms are more likely to be appointed president or chairman. Column 5 shows the first stage results for our instruments, and Columns 2 and 4 report the results of appointment changes on instrumented passive institutional ownership. Once we instrument passive ownership, increases in passive ownership lead to increases in the accumulation of titles for the CEO. A one percentage point increase in passive ownership increases the likelihood that the CEO becomes chairman by $1.7 \%$, and the likelihood that the CEO is president by $1.38 \%$. The effects are not only statistically, but also economically significant. The (unconditional) average annual change in CEO chairmanship and president positions are $2 \%$ and $2.6 \%$, respectively.

\subsubsection{Board composition}


We next examine whether exogenous increases in passive institutional ownership lead to changes at the board of directors level. Table 5 presents results for two sets of regressions. We first examine whether the fraction of independent directors changes after changes in passive ownership. The second set of results examines whether new independent director appointments are more likely after changes in passive institutional ownership. Although related, the two sets of results answer a slightly different question. The first question asks whether boards become more or less independent after changes in shareholder composition. The second question asks whether board turnover increases or decreases after changes in the shareholder base although board independence may stay constant. The second test of Table 5 is inspired by Shivdasani and Yermack (1999) who show that more powerful CEOs appoint fewer new independent directors.

The OLS regression of Table 5, Column 1 shows that the fraction of independent directors increases if passive institutional ownership increases. A $1 \%$ percent increase in passive institutional owners is associated with a 0.05 increase in independent directors. The other control variables do not have explanatory power for changes in board independence. Once we take the endogenous nature of institutional ownership into account and estimate IV regressions, changes in institutional ownership do not explain changes in board independence (Column 2).

Columns 4 and 5 show the results for the second test, the appointment of new independent directors as a fraction of board size. While the OLS regressions do not show an association between changes in passive ownership and new independent director appointments, the IV regressions show that an increase in passive ownership leads to fewer new independent directors. A one standard deviation increase in passive ownership (3.3) decreases the fraction of newly appointed independent board members relative to the board size by $1.3 \%$ $(0.39 \% \times 3.3)$. Table 2 shows that the average fraction of newly appointed independent board members is equal to $8 \%$. Hence, relative to the sample average, a one standard deviation increase in passive ownership reduces the fraction of newly appointed directors by $16 \%$. Regarding the control variables, we find that firms that experience large increases in assets and firms that are larger are more likely to appoint new board members. 
If one is willing to believe prior results that show that CEOs have the power to capture long-standing independent board members (for example, Mace, 1986), then our results indicate that while formal independence at the board level does not change, CEOs become more entrenched in that there are fewer new independent board members appointed. Our results are consistent with the findings of Shivdasani and Yermack (1999), who show that if the CEO has more power and may have more influence over the selection process of board members, fewer independent directors get appointed.

\subsubsection{Shareholder reactions to director appointments and increases in CEO power}

We now examine how the documented changes in governance are greeted by shareholders. We analyze the announcement returns of two governance changes - new independent director appointments and the accumulation of titles. We are careful to exclude appointment announcements if there are concurrent or adjacent confounding events such as mergers and acquisitions, publications of financial statements, or shareholder meetings. We analyze the time period after a reporting change to Form 8-K, the Exchange Act form for current reports. Since 2004, new director appointments and changes to the titles of executive officers must be disclosed on a Form 8-K within two business days (with an automatic extension of two business days). Because of this rule, we calculate cumulative abnormal returns over the window $[-4,0]$. Day " 0 " of this interval corresponds to the filing date of the Form 8-K. Since the event takes place before the filing date and is often announced via press releases, we feel confident that our choice of interval captures the announcement return. We calculate abnormal returns using a CAPM and a Fama and French four-factor-benchmark adjusted model. We follow Moeller, Schlingemann, and Stulz (2005) and estimate the parameters of the models using daily data during the $[-205,-6]$ window. Our results hold if we estimate the benchmark models over a shorter or longer period. We also tabulate results with no benchmark model ("raw" returns).

For new independent director appointments, we examine both the cross-section and time-series. We first ask whether shareholders react more negatively when a firm appoints a new independent director after exogenous increases in passive owners. Such a reaction would be consistent with shareholders believing that more powerful CEOs have more impact on the appointment of new independent directors, compromising the 
independence of the director (e.g., Shivdasani and Yermack, 1999). Importantly, we control for changes in board size in the regressions. Yermack (1996) shows that smaller boards are more effective. The addition of a new director could therefore lead to shareholder value decreases that are independent of the quality of the director that we seek to measure. Second, we ask whether shareholder reactions differ for the same firm for new independent director appointments before and after an exogenous increase in passive investors.

Our tests for the accumulation of titles by the CEO are more limited, because there are fewer observations. For those, we estimate whether the announcement returns to increases in CEO power are lower for firms with above-median changes in passive ownership than for firms with below median-changes in passive ownership.

Panel A of Table 6 shows the results for the announcement returns to new independent director appointments. Column 1 in Panel A shows the OLS regressions. A change in passive institutional ownership is negatively and significantly correlated with announcement returns. The larger the increase in passive ownership, the lower is the announcement return. Regarding the control variables, concurrent returns are positive and significant. If the firm performed well in the concurrent year, director appointment announcement returns are more positive. Columns 2 to 5 show the instrumental variable regressions. We find that an exogenous one percentage point increase in passive institutional ownership leads to 51 basis points lower independent director announcement returns if no benchmark model is used. In Column 3, we add the change in board size as a control and find that the effect becomes stronger. A one percentage point increase in ownership of passive institutional investors decreases appointment CARs by 65 basis points after we control for board size. The impact increases to 69 basis points if we use the CAPM to calculate CARs and to 66 basis points if we use the Fama-French four-factor model. The effect is economically sizeable. The average (median) firm in that regression has a market value of $\$ 8.8$ billion $(\$ 2.7$ billion) so that a CAR of minus 66 basis points reduces firm value by $\$ 58$ million ( $\$ 18$ million). The CAR is comparable to the finding by Fich (2005) who shows that gray appointees to the board exhibit a negative announcement return of 56 basis points. Shareholders appear to be more reserved about the true independence of the appointees after large changes in the shareholder base. Shivdasani and Yermack (1999) show that when the CEO is on the nominating committee and has the 
possibility to influence the selection process, the appointment returns for new independent board members are lower. We believe that our results are consistent with theirs, as it is likely that a more powerful CEO has more possibilities to influence nominating decisions of the board. It is worth pointing out the first stage results in Column 6. Although we need to use a shorter time period because of data constraints, the relevance condition for our instruments is fulfilled, and the economic magnitude of the changes in passive institutional ownership are large across index reassignments. Firms that switch from the Russell 1000 to the Russell 2000 experience an increase in passive ownership, and firms that switch from the Russell 2000 to the Russell 1000 experience a decrease in passive ownership.

Panel B of Table 6 shows time-series results. With these regressions, we examine the same firms and ask whether the new director announcement returns prior to the index switch are different from the announcement returns after the change. To conduct this test, we only keep firms that switch the index. We collect director appointments in the two years before the index switch, the year of the switch, as well as in the year immediately after.

We find that before firms switch from the Russell 1000 to the Russell 2000 index, the average CAR for new independent director appointments is $0.847 \%$ ( $t$-stat 1.40). After the stock moves to the Russell 2000 index, the CAR is $-0.793 \%$ ( $t$-stat -1.14$)$. Hence, we observe a statistically significant ( $p$-value 0.08 ) decline in director announcement returns for firms in which passive ownership increases because of an index reassignment. An analysis of median CARs yields the same conclusion. Before switching from the Russell 1000 to the Russell 2000 index, the median CAR is $0.678 \%$, while after the index switch the CAR drops to $0.942 \%$. A Wilcoxon rank-sum test confirms that the two are statistically different ( $p$-value 0.08$)$.

The findings are reversed for stocks moving in the opposite direction. Before firms switch to the Russell 1000 (and thus experience a decrease in passive ownership), their independent director appointments have an announcement return of $-0.13 \%$, statistically indistinguishable from zero. In the year of the switch and in the year after, the CAR increases to $1.073 \%$ ( $t$-stat 1.92 ). The corresponding median CARs are $-0.417 \%$ before the switch and $0.299 \%$ after. We observe an economically large increase in director announcement returns for firms in which passive ownership decreases because of an index reassignment, although it just 
misses statistical significance for means ( $p$-value 0.11 ). The median difference is weakly statistically significantly different from zero ( $p$-value 0.09$)$. Overall, the observed changes are supportive of our hypothesis. Investors assess that the increase in holdings by passive investors reduces monitoring and makes CEOs more powerful. These powerful CEOs in turn have more impact on the appointment of new independent directors and compromise the independence of the new director appointments. ${ }^{12}$ Note that this finding is consistent with our low-cost vs. high-cost monitoring hypothesis. Passive institutional investors or their proxy advisors monitor that the fraction of independent directors stays constant, but they do not have the capacity to monitor the type of independent director who is appointed.

In unreported regressions, we also examine how shareholders react to an accumulation of titles by CEOs, for two different groups of firms. The first group of firms has experienced an above-median change in passive institutional ownership, and the second group has experienced a below-median change in passive institutional ownership. We find that announcement returns for the first group of firms are economically significantly lower than the announcement returns for the second group of firms. The results are similar across the different specifications of cumulative returns (raw returns, market-model-adjusted, or Fama-French fourfactor model-adjusted). The market-model-adjusted average CARs for announcements that the CEO also becomes chairman or president are a negative $-0.829 \%$ but insignificant after above-median changes in passive ownership, and a positive $0.182 \%$ (statistically insignificant) after below-median changes in passive ownership. The difference is economically large, but because our sample size is small at 144 announcements, it is not statistically significant. An analysis of median CARs yields the same conclusions. The evidence is inconsistent with shareholders wishing that a strong board of directors temporarily concentrates power in the hands of the CEO to help the firm improve performance, because in that case the announcement return to increases in CEO power would have been positive after an increase in passive shareholders. The evidence is

12 We show earlier that fewer new independent directors get appointed after increases in passive ownership. Conditional on a turnover, Table 6 shows that new appointment CARs are negative. We believe that these results are not contradictory. Loyalty to the CEO is rewarded with longer tenure on average, but directors who might be more critical of the $\mathrm{CEO}$ are being turned over and replaced by directors more friendly towards the CEO, which causes the negative announcement returns to new director appointments. 
more consistent with shareholders believing that the CEO is more entrenched after changes to the shareholder base and that the concentration of power has negative consequences for firm performance.

\subsubsection{Shareholder proposals}

We examine whether the number of governance-related shareholder proposals changes after a change in passive institutional ownership. This test is motivated by the empirical finding that some well-diversified investors such as pension funds have actively used shareholder proposals (e.g., Carleton, Nelson, and Weisbach, 1998; Del Guercio and Hawkins, 1999). Table 7 shows the results. We estimate OLS and IV regressions of the change in the number of G-index-related shareholder proposals on changes in passive institutional ownership. The OLS regressions do not show a relation between changes in the number of shareholder proposals and changes in passive ownership. The IV regressions show a statistically significant negative effect. As passive institutional ownership increases, the number of governance-related shareholder proposals decreases. We note however that the effect is economically very small. Each $1 \%$ increase in passive institutional ownership leads to 0.014 fewer shareholder proposals.

Overall, we do not find evidence that passive index-tracking institutional investors use a broad basket of governance-related shareholder proposals more often. Our evidence is not inconsistent with the findings of Carleton, Nelson, and Weisbach (1998) or Del Guercio and Hawkins (1999). Both papers focus on a particular class of well-diversified investors, pension funds. Our focus is on changes in holdings by index-tracking institutions, the motivations of which are likely to be very different from those of pension funds. Appel, Gormley, and Keim (2016) argue that institutional investors do not have to initiate shareholder proposals if they can convince companies to pre-empt such proposals and implement changes before they come up for a vote. They find evidence consistent with their argument, which could help reconcile their and our findings.

\subsubsection{Merger and acquisition analyses}

Jensen (1986) argues that one way manager-shareholder conflicts manifest is through value-reducing acquisitions. Managers carry out these acquisitions if they can because they derive large personal gains from 
empire building. Lang, Stulz, and Walkling (1991) provide supportive evidence for Jensen's (1986) conjecture. Mitchell and Lehn (1990) show that firms with a history of value-reducing acquisitions are themselves more likely to become takeover targets. Their evidence is suggestive that new ownership of the firm can reduce manager-shareholder conflicts by replacing inefficient or entrenched management. Masulis, Wang, and Xie (2007) show that managers of firms with less effective corporate governance undertake more value-destroying acquisitions. Hence, there are theoretical predictions and empirical evidence showing that less oversight of managers might lead to worse acquisitions. We therefore examine next whether managers of sample firms in which passive ownership increases and governance potentially worsens (because passive owners have less incentives to monitor) carry out value-reducing mergers and acquisitions.

We start by examining certain deal characteristics of merger and acquisition deals for firms with different levels of passive ownership. Simple summary statistics show that firms with more passive institutional ownership carry out more all stock deals and in general pay a higher fraction of the deal consideration in stock. Firms with above-median passive institutional ownership have a $1.8 \%$ higher probability of an all stock deal ( $p$-value 0.007$)$ and pay, on average, $2.6 \%$ more of the deal consideration in stock ( $p$-value of 0.002). These findings suggest that firms with more passive institutional ownership undertake deals with characteristics that are usually correlated with lower acquirer returns in the literature (see, e.g., Betton, Eckbo, and Thorburn, 2008).

Panel A of Table 8 shows the results for the two-day cumulative announcement returns to the 9,125 merger and acquisition transactions of sample firms between 1993 and 2010. Column 1 shows the results from an OLS regression, and Columns 2 to 5 show the results from instrumental variable regressions with different sets of control variables and different calculations of cumulative abnormal returns. Columns 2 and 3 use raw returns, Column 4 uses market-model-adjusted returns, and Column 5 uses returns that are adjusted with a Fama-French four-factor model. We follow Moeller, Schlingemann, and Stulz (2005) and estimate the parameters used to calculate abnormal returns over the $[-205,-6]$ event window relative to the announcement day. Column 6 shows the first stage of the instrumental variable regression. We employ a set of control variables that is standard in M\&A CAR regressions (e.g., Masulis, Wang, and Xie, 2007; Moeller, 
Schlingemann, and Stulz, 2005; Fich, Harford, and Tran, 2015). In particular, we control for deal characteristics such as public or private status of the target (relative to the omitted group of subsidiary targets), method of payment, whether the transaction is diversifying, whether there are competing bidders, and whether the deal was hostile.

Column 1 of Table 8, Panel A shows that a change in passive ownership is not correlated with CARs in the OLS regression. Columns 2 to 6 show economically and statistically large effects once we use the instrumented changes in passive institutional ownership. A $1 \%$ increase in passive ownership leads to 0.32 to $0.38 \%$ lower M\&A announcement returns, depending on the specification, and a one standard deviation increase in passive ownership leads to about $1 \%$ lower announcement returns. Multiplied with the previous year's average market capitalization of $\$ 3.908$ billion, the coefficient estimate of $0.38 \%$ translates into an economically important value reduction of $\$ 15$ million. The result is robust to using a market model (Column 4) or the Fama-French four-factor model (Column 5) to calculate cumulative abnormal returns. Regarding the control variables, we find coefficients that are similar to those reported in earlier papers (e.g., Masulis, Wang, and Xie, 2007; Moeller, Schlingemann, and Stulz, 2005). Deals with public and private targets (relative to the omitted base group of subsidiary targets), deals financed with more stock, and deals carried out by larger acquirers have lower announcement returns. Our findings support the hypothesis that managers at firms with more passive ownership are less subject to monitoring by their shareholders and are thus more likely to engage in $M \& A$ transactions that reduce shareholder value.

In Panel B of Table 8 we analyze acquisition announcement returns of firms before and after these firms switch from the Russell 1000 to the Russell 2000 index or vice versa. We collect M\&A announcement returns in the two years prior to the index switch, and in the year of and the year after the index switch. Column 1 of Table 8, Panel B shows that firms exhibit an average M\&A announcement return of $0.948 \%(t$ stat 2.87) before moving to the Russell 2000 index. After switching to the Russell 2000 index, these firms have an average CAR of $-0.075 \%$, statistically indistinguishable from zero. The difference (after minus before) is statistically significantly negative ( $p$-value 0.027 ). We reach the same conclusion using medians. Before the index switch, the median CAR is $0.213 \%$, while after the index switch the announcements have a median CAR 
of $-0.246 \%$. The difference is statistically significant ( $p$-value 0.014 ). After firms move from the Russell 1000 to the Russell 2000 and experience an increase in passive ownership, the announcement returns to their M\&A activity significantly decrease. If stocks move in the opposite direction, the findings are reversed. Before switching, i.e., when these firms are part of the Russell 2000 index, the average announcement return is $0.069 \%$ ( $t$-value -0.27$)$. After joining the Russell 1000, the CAR increases to $1.258 \%$, which is statistically significant. The difference (after minus before) between the two coefficients is statistically significantly positive with a high level of confidence ( $p$-value 0.0001 ). The corresponding figures for the median are $0.150 \%$ (before the switch) and $0.427 \%$ (after the switch). The difference (after minus before) stays statistically significant ( $p$-value 0.006). Hence, after firms experience exogenous decreases in passive ownership, their acquisition announcement returns improve.

Overall, our results are consistent with our high-cost monitoring hypothesis and provide important new evidence that once monitoring becomes more costly (as it is not easy for outside passive shareholders to assess the quality of targets and continuously monitor the investment activities of their portfolio firms), passive investors have more difficulty monitoring the firm's managers and these managers take advantage of it.

Our results in Table 8 complement the recent findings of Fich, Harford, and Tran (2015). Fich, Harford, and Tran (2015) examine the role of active institutional owners with monitoring incentives in merger and acquisition negotiations. In their sample of public to public deals, they focus on the importance of the ownership of monitoring institutions in the target and show that more monitoring institutional ownership in the target firm pushes the target to negotiate a higher deal premium. As a consequence, the acquirer announcement returns decrease. ${ }^{13}$ In our paper, we concentrate on passive ownership in the acquirer. We test the hypothesis that acquirer announcement returns are lower because passive institutional investors in the

13 Fich, Harford, and Tran's (2015) main focus is on institutional ownership in the target, but they also analyze whether monitoring institutional ownership in the acquirer affects the deal premium, deal completion, and announcement returns and find no effect. Fich, Harford, and Tran (2015) argue that in merger negotiations, shareholders of the target have a critical need of shareholder coordination and have more bargaining power relative to shareholders of the acquirer. 
acquirer do not monitor managers of the acquiring firm and they undertake bad deals. The results in Table 8 appear to support our hypothesis.

\section{Robustness}

We provide several additional tests that we hope alleviate concerns regarding the sample period, our focus on index switchers, and our proxy for passive institutional investors.

\subsection{Restricting the sample period to $1992-2006$}

We examine whether our results hold before Russell introduced the banding policy that altered the index assignment rules in 2007. With the new policy, Russell keeps a stock in its current index if the stock experienced only a modest change in market capitalization. While our estimation approach exploits the actual index switching stocks and, in turn, is immune to this banding policy, the number of index switching firms decreases with the banding policy. In addition, the banding policy introduces noise in the otherwise clear rule of index assignment based on raw market capitalization. Therefore, we repeat our previous analysis and end the sample in 2006.

Our results are robust to the alternative sample period, and some become stronger. The likelihood to add or loose titles does not vary much across samples. The coefficient estimate to become chairman is 1.5 ( $p$ value 0.051 ) instead of 1.7 , while the one for president moves from 1.38 to 1.1 ( $p$-value 0.169 ). The results on board independence do not change (estimate is -0.24 instead of -0.16 with $p$-value of 0.285 ). The impact of passive institutional investor changes on the turnover of new independent board members becomes stronger. It increases from -0.39 to -0.56 ( $z$-value -2.37 ). Our result for acquisition announcements is virtually unchanged. For example, the CAR estimated with a Fama-French four-factor model corresponds to $-0.35 \%$ ( $p$-value 0.033 ) instead of $-0.32 \%$.

\subsection{Restricting the magnitude of the change in market capitalization of switchers}


Our identification comes from firms who switch from one Russell index to the other. The index switch affects the level of passive ownership and therefore allows us to study whether passive ownership triggers changes in corporate governance. We identify the effect of changes in passive ownership on firms using 1,242 moves from the Russell 1000 to the Russell 2000 and 1,414 changes from the Russell 2000 to the Russell $1000 .{ }^{14}$ There is a potential concern that, by definition, index switchers experience a change in market capitalization and that this change in market capitalization violates the exclusion restriction that the index switch only influences governance through its impact on passive institutional ownership. We first note that we control for concurrent and past returns. Second, some of our results are contrary to what one may expect under this concern: We observe that after decreases in market capitalization (and thus poor past returns), the CEO increases his power. We nevertheless try to alleviate the concerns and re-estimate our regressions by only using index-switching firms that changed by at most 500 ranks from one year to the next. The 500 rank criterion is borrowed from Appel, Gormley, and Keim (2016) who restrict in their analysis the bandwidth of firms to minus 500 and plus 500 firms around the index-reconstitution threshold. The likelihood to become chairman increases from 1.7 to 2.2 percentage points, but the effect disappears for the likelihood to become president. There is no effect for board independence or shareholder proposals. For the announcement returns of director appointments we find a virtually unchanged result. The coefficient estimate decreases from - 0.66 to -0.68 but maintains a $p$-value of 0.024 . The effect for M\&A announcement returns continues to be negative, but ceases to be significant. Overall, we observe that some, but not all of our results hold in this more limited sample.

The robustness test in Section 5.2. points to a common problem in all studies on index-reconstitutiondriven changes in passive ownership. The experiment is cleanest using tight bounds around the indexreconstitution threshold, but there are not that many firms that switch positions by only a handful of raw market capitalization ranks. Hence, the smaller the bandwidth, the lower is the number of observations, and the lower the precision of the estimate.

14 These figures correspond to the overall sample period (compare Column 1 in Table 3 ). 


\subsection{Usage of a modified Bushee (2001) measure of total passive institutional ownership}

We now compare our results to those obtained with a coarser measure of passive institutional ownership. We redo our previous analysis using the (permanent) investor categories defined by Bushee (2001). Bushee (2001) defines three categories of institutional investors - quasi-indexers, transient, and dedicated institutional investors. Most researchers use the category "dedicated investors" to identify active institutional investors (e.g., Chen, Harford, and Li, 2007).We therefore define our alternative measure of passive ownership as all institutional ownership less dedicated investors less non-dedicated public and private pension funds (because they also tend to be more active in monitoring). The likelihood to become chairman and president continues to significantly increase after an exogenous increase in passive institutional investors. Regarding board characteristics, we continue to find a statistically significant decrease in new director appointments. Our finding regarding the announcement effect for director appointments remains economically sizable (coefficient -0.14 ), but loses statistical significance ( $p$-value 0.128 ). We continue to find a statistically significant negative effect for acquisition announcement returns ( $z$-stat of -2.08). The overall takeaway is that some of our results are robust to the coarser measure of passive institutional investors, but that for some tests the definition of passive institutional ownership can alter the statistical significance of the results. ${ }^{15}$

\section{Conclusion}

We find that an increase in passively managed institutional ownership appears to have consequences for the governance of corporations. Our results indicate that managers become more powerful after exogenous increases in passive institutional ownership. We concentrate on areas that can be changed quickly after a change in the balance of power in corporations. Managers appear to be able to obtain more power by accumulating more titles, and there are relatively fewer new independent directors appointed after increases in

15 The emerging literature on index-reconstitution-driven changes in passive ownership agrees that identification comes from Russel-indexes tracking institutions, but has chosen different ways to measure the fraction held by these passive investors (e.g., Appel, Gormley, and Keim, 2016; Crane, Michenaud, and Weston, 2016; Boone and White, 2015). All papers' identification strategy, including ours, is based on the assumption that the change in passive institutional investors' ownership (in our case, $3 \%$ ) caused by the index reconstitution is important enough to be recognized by managers and shareholders and to shift the relative power of the affected parties. 
passive ownership. The corporate governance changes we document appear to have negative consequences for firm value. Shareholders react more negatively to announcements of new director appointments after an increase in passive ownership. Executives are able to carry out more value-destroying mergers and acquisitions after exogenous changes in passive ownership.

Recent literature shows that passive institutional investors engage successfully in relatively low-cost governance activities. Our paper adds to the literature by examining managerial actions that are more difficult and costly to monitor for investors. Overall, our evidence suggests that passive institutional investors may not have the capacity for high-cost governance activities that require continuous monitoring such as, for example, the M\&A activity of corporations. We note, however, that several of our results are sensitive to how passive institutional investors are defined. Also, because we use firms that switch the index for identification, some of the change in passive institutional ownership that firms experience could be due to a change in their performance. Despite these issues, the evidence we present suggests that an exogenous increase in passive ownership weakens the corporate governance of the affected firms. 


\section{Appendix A. Construction of the Russell indexes, validity of instrumental variables based on the annual}

reconstitution of the Russell 1000 and 2000 indexes, and details on the market capitalization calculations

The construction of the Russell indexes is based on the following procedure. On the last trading day in May each year Russell ranks all US stocks by their raw market capitalization. The largest 1,000 stocks become or remain part of the Russell 1000 index. Stocks with a rank between 1,001 and 3,000 comprise the Russell 2000 index. The index weight that each stock receives within the Russell 1000 and within the Russell 2000 is however not determined by the stock's raw market capitalization. Russell Investments instead adjusts the raw market capitalization for shares not part of the free-float using a proprietary measure and then calculates the index weight based on the float-adjusted market cap within the corresponding index. The index reconstitution including the assignment of new index weights takes place in June.

The free-float adjustment can lead to important differences between a rank based on raw market capitalization and a rank based on index weights. For example, CNH Global had a raw market capitalization rank of 412 in the index reconstitution year 2010. However, the majority shareholder Fiat S.P.A. held $89 \%$ of the shares outstanding, and Russell Investments removed Fiat's stake in the free-float adjustment. Therefore, the Russell 1000 rank of CNH Global, based on float-adjusted index weights, was only 973 in 2010.

The two-step procedure outlined above makes usage of the Russell 1000/2000 index reconstitution for identification of exogenous ownership changes so challenging. The economic argument for why passive institutional ownership changes with an index reassignment is based on end-of-June index weights calculated on the basis of free-float adjusted market cap. The actual assignment to the Russell 1000 or Russell 2000 index, where firms are close to each other and index inclusion is locally random around the threshold, is instead based on raw market capitalization weights at the end of May.

The above example of $\mathrm{CNH}$ Global already indicates that the free-float adjusted index weights within each index are inappropriate for identification. In a free-float-adjusted ranking, the lowest ranked stocks in the Russell 1000 will be those that have the smallest free-float, i.e., they are more likely to have strategic shareholders or significant inside ownership, while the highest ranked stocks in the Russell 2000 will be those that are the most liquid. Appel, Gormley, and Keim (2016), Mullins (2014), and Chang, Hong, and Liskovich 
(2015) provide more details on this point. The free-float adjustment leads firms at the bottom of the Russell 1000 to have very different characteristics from firms at the top of the Russell 2000 which invalidates random assignment close to the threshold. But also, more subtly, any sample selection that is based on index weights (for example, carrying out an analysis using the bottom 250 stocks in the Russell 1000 and the top 250 stocks in the Russell 2000 based on index weights) is problematic for the same reasons.

A ranking based on the raw market capitalization is not prone to the same drawback. Because stocks are only ranked by market capitalization, there is no reason to suspect that there are systematic differences in stocks that just fall above or below the threshold that determines whether a firm is in the Russell 1000 or Russell 2000. But it is important to stress that the key assumption of the experiment is that the actual rank and index weight based on the free-float adjustment is not too different from the rank based on raw market capitalization. To illustrate, suppose that a stock assigned to the Russell 1000 with a raw market cap position of 999 neither has a large shareholder nor significant inside ownership so that it moves after the free-float adjustment of all Russell 1000 stocks to a rank based on index weights of 750 . At the same time, the stock with a raw market cap position of 1,001 assigned to the Russell 2000 has a large strategic shareholder and moves to rank 1,250. The difference in the index weights between positions 750 and 1,250 will not be as large as a difference between the index weights assigned to stocks at the rank of 999 and 1,001, and the smaller difference means that the changes in the holdings of index-tracking institutional investors will be smaller, and identification of exogenous changes in ownership will be muted.

The second issue with using the index reassignment as an experiment stems from the fact that researchers do not have access to Russell's market capitalization ranking, and that perfectly recreating that ranking from publicly available sources is not possible. Raw market capitalization calculations are complicated for dual-class firms with non-traded share classes or firms with tracking stock. But because a researcher does not know the precise data source of Russell, which Russell keeps proprietary, it is also not possible to rank single-class stocks very close to the threshold correctly. ${ }^{16}$ This problem is shared by all

16 We know the actual index assignment of each stock from data provided by Russell, and we can rank stocks by our measure of raw market capitalization and assign stocks to our hypothetical index. We can then isolate firms which are 
researchers who use the Russell 1000 / 2000 index reconstitution as an identification strategy, and it is this problem that makes a standard regression discontinuity approach complicated (see Appel, Gormley, and Keim, 2016; Crane, Michenaud, and Weston, 2016).

It is nevertheless important to calculate end-of-May market capitalization as precisely as possible to rank order firms because one would like to know how close they were to maintaining or losing their index status. We follow the following procedure. We download the market capitalization from Capital IQ as of the last trading day in May each year. We drop this estimate if the reported shares outstanding are below $90 \%$ of the free-float-adjusted shares reported by Russell, because by definition free-float-adjusted shares cannot be smaller than the total shares outstanding. If the data from Capital IQ are missing or erroneous, we use data from Compustat, following the procedure outlined in Chang, Hong, and Liskovich (2015). If neither data from Capital IQ nor data from Compustat are available, we take shares outstanding and prices from CRSP at the end of May. If a stock has multiple traded classes, we sum the market capitalization of all permnos with the same CRSP permanent company number. We believe that relative to other papers who have used a similar setup, our market capitalization calculations are the closest to what Russell actually does. In particular, it is important to calculate market capitalization correctly for dual-class firms with non-traded classes of stock, which is not possible if one calculates market capitalization using CRSP. Dual-class firms are likely to have different corporate governance arrangements, and systematically misclassifying them could lead to a bias.

We produce several graphs to inspect the properties of our raw market capitalization measure and its implications for our experimental design. Fig. 2 contains six graphs for a sample period from 1992 to 2006, while Fig. 3 shows the same graphs for an extended sample period of 1992 to 2010 . We include a figure for both periods because Russell Investments introduced the new banding policy in 2007 which allowed firms to maintain their index assignment if they just missed the threshold. Fig. 2 is based on a sample period in which there was a mechanical rule to assign the index and Fig. 3 allows the reader to evaluate how the sample properties changed during the more flexible period. The top left panel in each figure shows the fraction of threshold, the more likely one is to erroneously assign stocks to the wrong index. 
stocks in the Russell 2000 index. If our sorting variable was perfect, all stocks on the right side of the cutoff would be part of the Russell 2000 index in Fig. 2. We find that this is almost the case, except for stocks in the bandwidth 1,001 -1,025, in which $20 \%$ of the stocks are Russell 1000 stocks. If we compare the top left panel of Fig. 2 with the same panel in Fig. 3, we find that the fraction of stocks that are wrongly assigned increases, as one would expect. We nevertheless see that being on the right side of the threshold strongly increases the probability of being included in the Russell 2000.

The top middle panel shows our market capitalization measure as a function of raw market capitalization rank. Since we sort all stocks by raw market capitalization we do not find any discontinuities. The top right panel follows the approach suggested by Lee and Lemieux (2010) to plot the relative distribution of observations around the cutoff of the forcing variable to detect any manipulations. We adapt their idea for repeated cross-sections and plot the index switching probability of firms around the cutoff of 1,000 as a diagnostic. The top right panel shows that the ranking based on raw market capitalization gives the expected bell-shaped curve for the index switching probabilities. Firms in the Russell 1000 index which become smaller have an increasing probability of switching to the Russell 2000 index in the next year, and Russell 2000 index firms that become larger have an increasing probability of switching to the Russell 1000 index. The curve before banding (Fig. 2) is more pronounced in comparison to the curve that covers the complete sample period (Fig. 3).

Since our analysis makes assumptions regarding which passive owners are affected by the experiment, we also plot three different measures of institutional ownership around the index-reconstitution threshold in the three lower panels of Fig. 2 and Fig. 3. We include the holdings of Russell 1000 and 2000 tracking passive investors (left panel), the holdings by quasi-index tracking passive institutional investors according to the QIX classification of Bushee (2001) (middle panel), and the shareholdings of all institutional investors who need to file Form 13f (right panel). We find that stocks just included in the Russell 2000 index have around 2\% more passive institutional holdings. Interestingly, there is no such pronounced change if we plot the fraction of shares held by quasi-index tracking institutions or the fraction of shares held by all institutional investors. 
We believe that the conclusion from Fig. 2 and Fig. 3 is threefold. First, our market capitalization ranking closely mirrors the unobserved ranking used by Russell Investments. Second, although the banding policy introduced by Russell in 2007 dampens the effect of index switching somewhat, all our diagnostics from the pre-banding period underlying Fig. 2 also apply to Fig. 3, which makes us believe we can use the entire sample period in our research design. Third, we believe it is very important to identify precisely which institutions actually track the Russell 1000 and Russell 2000 and are subject to index-reconstitution-driven changes in ownership because otherwise the jump in ownership is less pronounced. Just looking at all institutions that are considered quasi-indexers mixes the active funds and passive index-tracking funds of large fund families, and also outright misclassifies some funds known to be active.

\section{Appendix B. Crawling data on director appointments and accumulation of titles for CEO}

\section{B.1. Crawling director appointment dates}

We download SEC filings following the approaches described in Garcia and Norli (2012) and Engelberg and Sankaraguruswamy (2007). We obtain a list of new directors in a given year from IRRC/RiskMetrics. Directors are considered new appointments if their full name appears for the first time in the proxy information at a shareholder meeting date of a given firm. For all firms with new directors we search 8-K filings that include an item 5.02 paragraph. In item 5.02 paragraphs, firms disclose information related to the "Departure of Directors or Principal Officers; Election of Directors; Appointment of Principal Officers;". We search the item 5.02 paragraph for the new director's last name. We limit the search window to +15 days relative to the meeting date at which the name appeared first and to -15 days relative to the meeting date at which the name was not mentioned. We merge the 8-K filings via the Employer Identification Number (EIN) and the Central Index Key (CIK) identifier to our sample. Firms do not need to file separate 8-Ks if they report the information on new directors in item 5 "Other Information" of a 10-Q, or as item 9B "Other Information" in a $10-\mathrm{K}$, and if the appointment date is covered by the $10-\mathrm{Q}$ or $10-\mathrm{K}$ statement. We do not use appointment dates from 10-Ks and 10-Qs because they almost always also contain other price-relevant information. For practicability, we truncate the lines analyzed in the item 5.02 to 100 lines and to a maximum of 32,000 
characters. If there are several filings that contain a director's last name, the first filing likely contains the appointment news. However, we also manually check all item 5.02 paragraphs of our sample to verify their content.

We eliminate observations if the 8 -K filing also contains information on a merger and if there was a non-independent director appointed concurrently. Finally, we eliminate 8-K filings if the filing was filed within four calendar days of another $8-\mathrm{K}, 10-\mathrm{K}$, or 10-Q statement or in the four calendar days around a shareholder meeting. These restrictions yield a final sample of 2,138 different dates for 2,415 different directors.

\section{B.2. Crawling data to identify when a CEO gains or loses the title of president or chairman}

We follow a very similar approach to collect data on the appointment of CEOs as president or chairman. We compile a list of CEO names from ExecuComp at the end of each fiscal year. We collect all 8-K filings in the two years before and the year after the fiscal year-end date at which we observe the CEO name. We require that the item 5.02 paragraph contains the CEO's last name and the word "CEO" or "Chief Executive Officer." We also require that the text contains a description of the president or chairman of the board. 


\section{References}

Adams, R., Almeida, H., Ferreira, D., 2005. Powerful CEOs and their impact on corporate performance. Review of Financial Studies 18, 1403-1432.

Adams, R., Almeida, H., Ferreira, D., 2009. Understanding the relationship between founder-CEOs and firm performance. Journal of Empirical Finance 16, 136-150.

Admati, A., Pfleiderer, P., 2009. The "Wall Street Walk" and shareholder activism: exit as a form of voice. Review of Financial Studies 22, 2645-2685.

Aghion, P., Van Reenen, J., Zingales, L., 2013. Innovation and institutional ownership. American Economic Review 103, 277-304.

Anderson, R., Reeb, D., 2003. Founding-family ownership and firm performance: evidence from the S\&P 500. Journal of Finance 58, 1301-1328.

Appel, I., Gormley, T., Keim, D., 2016. Passive investors, not passive owners. Journal of Financial Economics 121, 111-141.

Bertrand, M., Mullainathan, S., 2001. Are CEOs rewarded for luck? The ones without principals are. Quarterly Journal of Economics 116, 901-932.

Betton, S., Eckbo, B., Thorburn, K., 2008. Corporate takeovers. In: Eckbo B. E. (ed.), Handbook of Corporate Finance: Empirical Corporate Finance, vol. 2. Elsevier/North-Holland Handbook of Finance Series, Amsterdam, Netherlands, pp. 291-430.

Boone, A., White, J., 2015. The effect of institutional ownership on firm transparency and information production. Journal of Financial Economics 117, 508-533.

Brav, A., Jiang, W., Partnoy, F., Thomas, R., 2008. Hedge fund activism, corporate governance, and firm performance. Journal of Finance 63, 1729-1775.

Brickley, J., Lease, R., Smith, C., 1988. Ownership structure and voting on antitakeover amendments. Journal of Financial Economics 20, 267-91.

Bushee, B., 2001. Do institutional investors prefer near-term earnings over long-run value? Contemporary Accounting Research 18, 207-246.

Carleton, W., Nelson, J., Weisbach, M., 1998. The influence of institutions on corporate governance through private negotiations: evidence from TIAA-CREF. Journal of Finance 53, 1335-1362.

Chang, Y., Hong, H., Liskovich, I., 2015. Regression discontinuity and the price effects of stock market indexing. Review of Financial Studies 28, 212-246.

Chen, X., Harford, J., Li, K., 2007. Monitoring: which institutions matter? Journal of Financial Economics 86, 279-305. 
Crane, A., Michenaud, S., Weston, J., 2016. The effect of institutional ownership on payout policy: evidence from index thresholds. Review of Financial Studies 29, 1377-1408.

Cronqvist, H., Fahlenbrach, R., 2009. Large shareholders and corporate policies. Review of Financial Studies 22, 3941-3976.

Cuñat, V., Gine, M., Guadalupe, M., 2012. The vote is cast: the effect of corporate governance on shareholder value. Journal of Finance 67, 1943-1977.

Dasgupta, A., Piacentino, G., 2015. The Wall Street Walk when blockholders compete for flows. Journal of Finance 70, 2853-2896.

Davis, G., Kim, E., 2007. Business ties and proxy voting by mutual funds. Journal of Financial Economics 52, 293-340.

Del Guercio, D., Hawkins, J., 1999. The motivation and impact of pension fund activism. Journal of Financial Economics 52, 293-340.

Diamond, D., 1984. Financial intermediation and delegated monitoring. Review of Economic Studies 51, $393-$ 414.

Edmans, A., 2009. Blockholder trading, market efficiency, and managerial myopia. Journal of Finance 64, 2481-2513.

Edmans, A., 2014. Blockholders and corporate governance. Annual Review of Financial Economics 6, $23-50$.

Edmans, A., Manso, G., 2011. Governance through trading and intervention: a theory of multiple blockholders. Review of Financial Studies 24, 2395-2428.

Engelberg, J., Sankaraguruswamy, S., 2007. How to gather data using a web crawler: an application using SAS to search EDGAR. Unpublished working paper. University of California, San Diego.

Fahlenbrach, R., 2009. Founder-CEOs, investment decisions, and stock market performance. Journal of Financial and Quantitative Analysis 44, 439-466.

Fahlenbrach, R., Low, A., Stulz, R., 2014. Do independent director departures predict future bad events? Unpublished working paper. Ohio State University.

Fich, E., 2005. Are some outside directors better than others? Evidence from director appointments by Fortune 1000 firms. Journal of Business 78, 1943-1972.

Fich, E., Harford, J., Tran, A., 2015. Motivated monitors: the importance of institutional investors' portfolio weights. Journal of Financial Economics 118, 21-48.

Garcia, D., Norli, O., 2012. Crawling EDGAR. The Spanish Review of Financial Economics 10, 1-10.

Gillan, S., Starks, L., 2007. The evolution of shareholder activism in the United States. Journal of Applied Corporate Finance 19, 55-73.

Gompers, P., Ishii, J., Metrick, A., 2003. Corporate governance and equity prices. Quarterly Journal of Economics 118, 107-155. 
Hartzell, J., Starks, L., 2003. Institutional investors and executive compensation. Journal of Finance 58, 23512374.

Investment Company Institute, 2014. 2014 Investment Company Fact Book, $54^{\text {th }}$ edition. Washington, DC.

Jensen, M., 1986. Agency costs of free cash flow, corporate finance, and takeovers. American Economic Review Papers and Proceedings 76, 323-329.

Lang, L., Stulz, R., Walkling, R., 1991. A test of the free cash flow hypothesis: the case of bidder returns. Journal of Financial Economics 29, 315-336.

Lee, D., Lemieux, T., 2010. Regression discontinuity designs in economics. Journal of Economic Literature 48, 281-355.

Levit, D., 2014. Soft shareholder activism. Unpublished working paper. University of Pennsylvania.

Linck, J., Netter, J., Yang, T., 2008. The determinants of board structure. Journal of Financial Economics 87, $308-328$.

Mace, M., 1986. Directors: Myth and Reality. Harvard Business School Press, Boston, MA.

Malenko, N., Shen, Y., 2016. The role of proxy advisory firms: evidence from a regression-discontinuity design. Review of Financial Studies, Forthcoming

Masulis, R., Mobbs, S., 2014. Independent director incentives: where do talented directors spend their limited time and energy? Journal of Financial Economics 111, 406-429.

Masulis, R., Wang, C., Xie, F., 2007. Corporate governance and acquirer returns. Journal of Finance 62, 18511889.

McCahery, J., Sautner, Z., Starks, L., 2016. Behind the scenes: the corporate governance preferences of institutional investors. Journal of Finance 71, 2905-2932.

Mitchell, M., Lehn, K., 1990. Do bad bidders become good targets? Journal of Political Economy 98, 372398.

Moeller, S., Schlingemann, F., Stulz, R., 2005. Wealth destruction on a massive scale? A study of acquiring firm returns in the merger wave of the late 1990s. Journal of Finance 60, 757-782.

Morck, R., Shleifer, A., Vishny, R., 1989. Alternative mechanisms for corporate control. American Economic Review 79, 842-852.

Morse, A., Nanda, V., Seru, A., 2011. Are incentive contracts rigged by powerful CEOs? Journal of Finance $66,1779-1821$.

Mullins, W., 2014. The governance impact of index funds: evidence from regression discontinuity. Unpublished working paper. University of Maryland.

Naveen, L., 2006. Organizational complexity and succession planning. Journal of Financial and Quantitative Analysis 41, 661-684. 
Petajisto, A., 2013. Active share and mutual fund performance. Financial Analysts Journal 69, 73-93.

Roe, M., 1990. Political and legal restraints on ownership and control of public companies. Journal of Financial Economics 27, 7-41.

Russell Investments, 2011. Russell U.S. equity indexes: construction and methodology, http://www.russell.com/indexes/documents/methodology.pdf.

Shivdasani, A., Yermack, D., 1999. CEO involvement in the selection of new board members: an empirical analysis. Journal of Finance 54, 1829-1853.

Shleifer, A., Vishny, R., 1986. Large shareholders and corporate control. Journal of Political Economy 94, 461-488.

Woidtke, T., 2002. Agents watching agents? Evidence from pension fund ownership and firm value. Journal of Financial Economics 63, 99-131.

Yermack, D., 1996. Higher market valuation of companies with a small board of directors. Journal of Financial Economics 40, 185-211. 


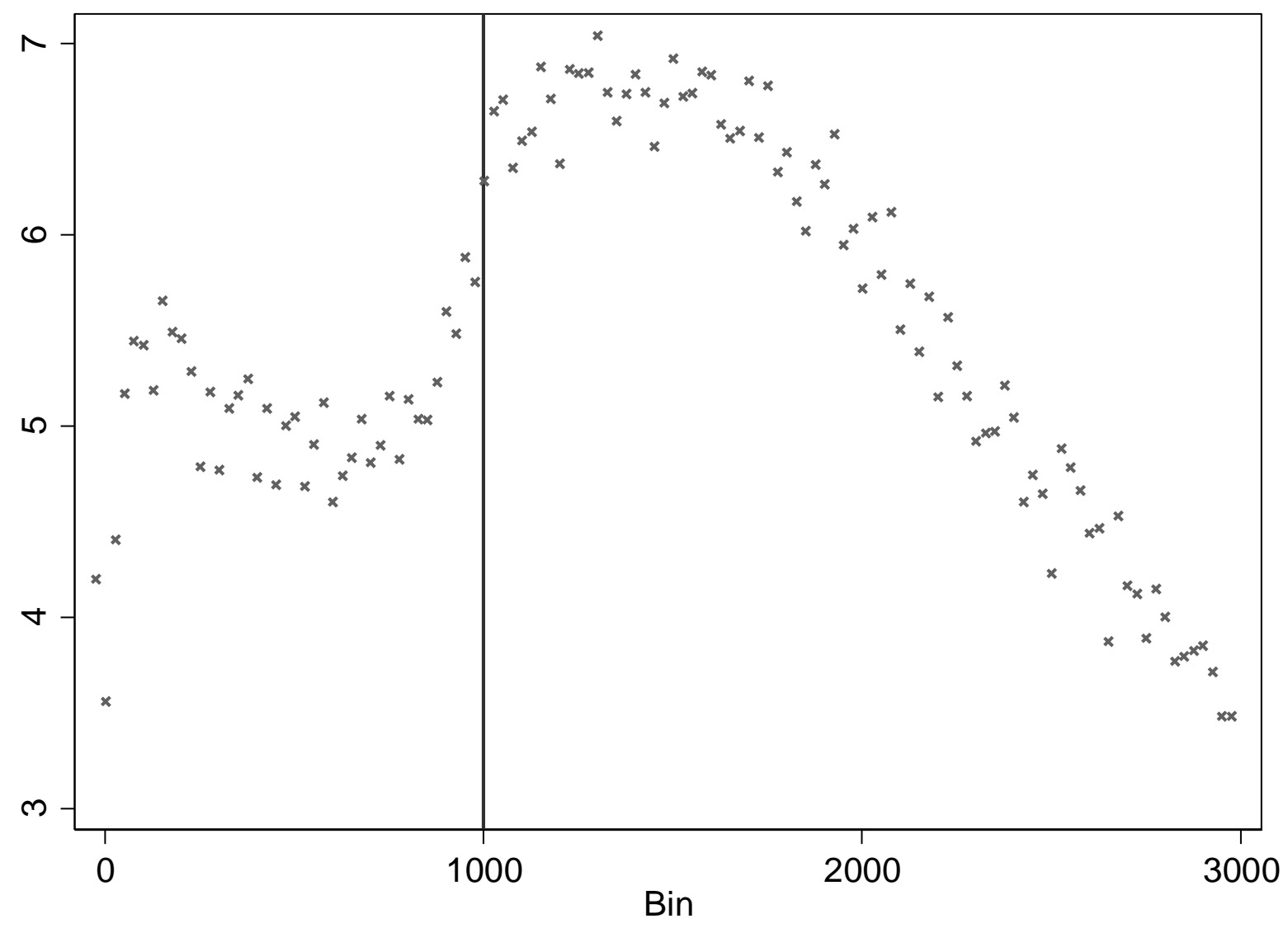

Fig. 1. Shareholdings by passive institutional investors around the index reconstitution threshold. The figure shows the level of passive institutional ownership by Russell 1000 and Russell 2000 index-tracking institutions. Each marker in the figure corresponds to the average holding of passive investors for a bin of 25 stocks. The vertical line at 1,000 indicates the index reconstitution threshold. Stocks to the left of the line are members of the Russell 1000, and stocks to the right of the line are members of the Russell 2000. Sample period is 1992 to 2010. 

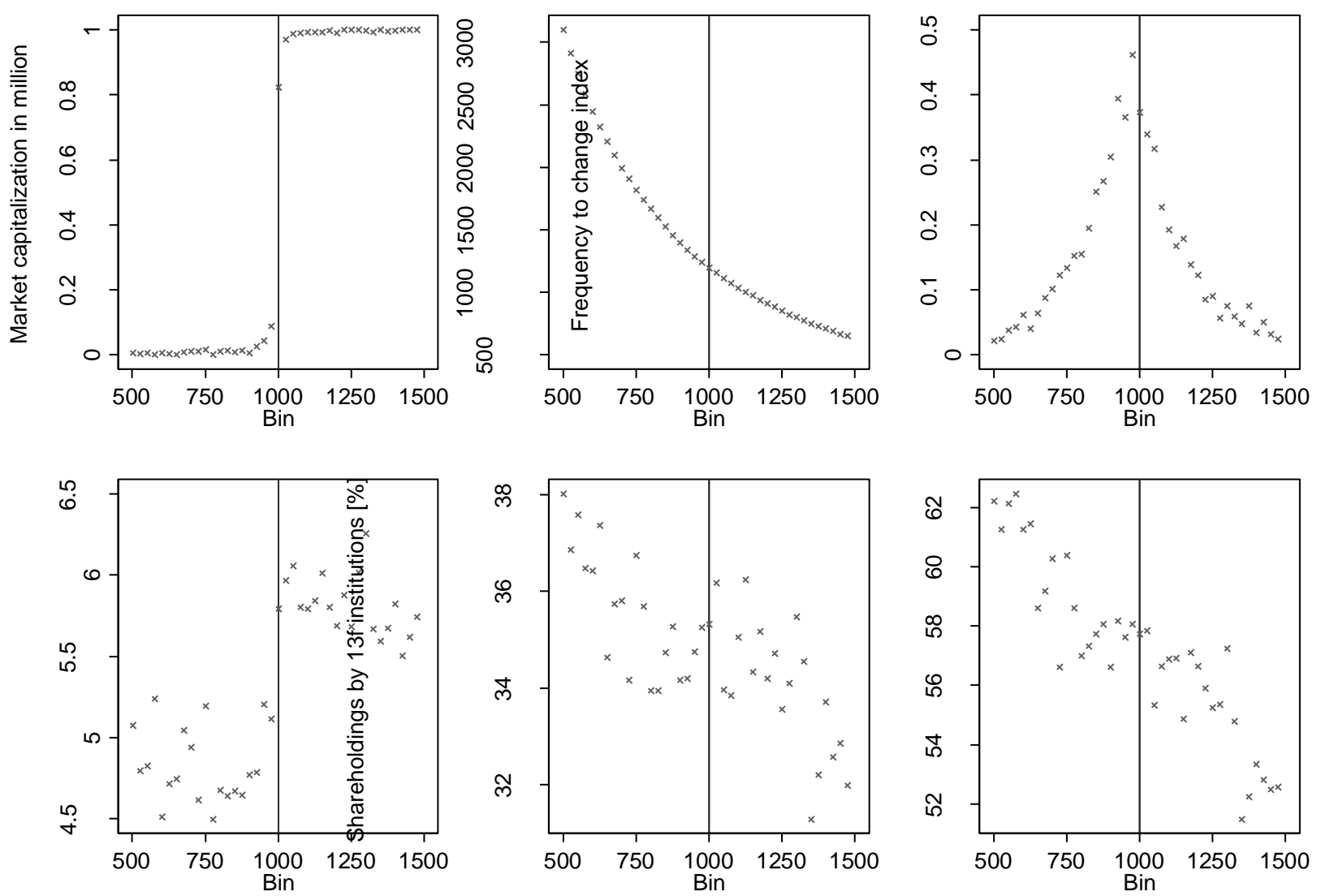

Fig. 2. Russell index assignment and passive institutional ownership, 1992-2006. The figure shows six graphs that support the validity of our empirical approach. The top left panel shows the fraction of firms in the Russell 2000 index, the top middle panel shows the (raw) market capitalization around the index threshold, and the top right panel shows the index switching probability. The three panels at the bottom show shareholdings of passive Russell 1000 and Russell 2000 investors combined (left panel), quasi-index tracking institutional investors (QIX) according to Bushee's (2001) classification (middle panel), and all institutional investors that file Form $13 \mathrm{f}$ (right panel). Stocks to the left of the vertical index threshold line should be members of the Russell 1000, and stocks to the right of the line are members of the Russell 2000. The sample period is 1992 to 2006. Bin size is 25 stocks. 

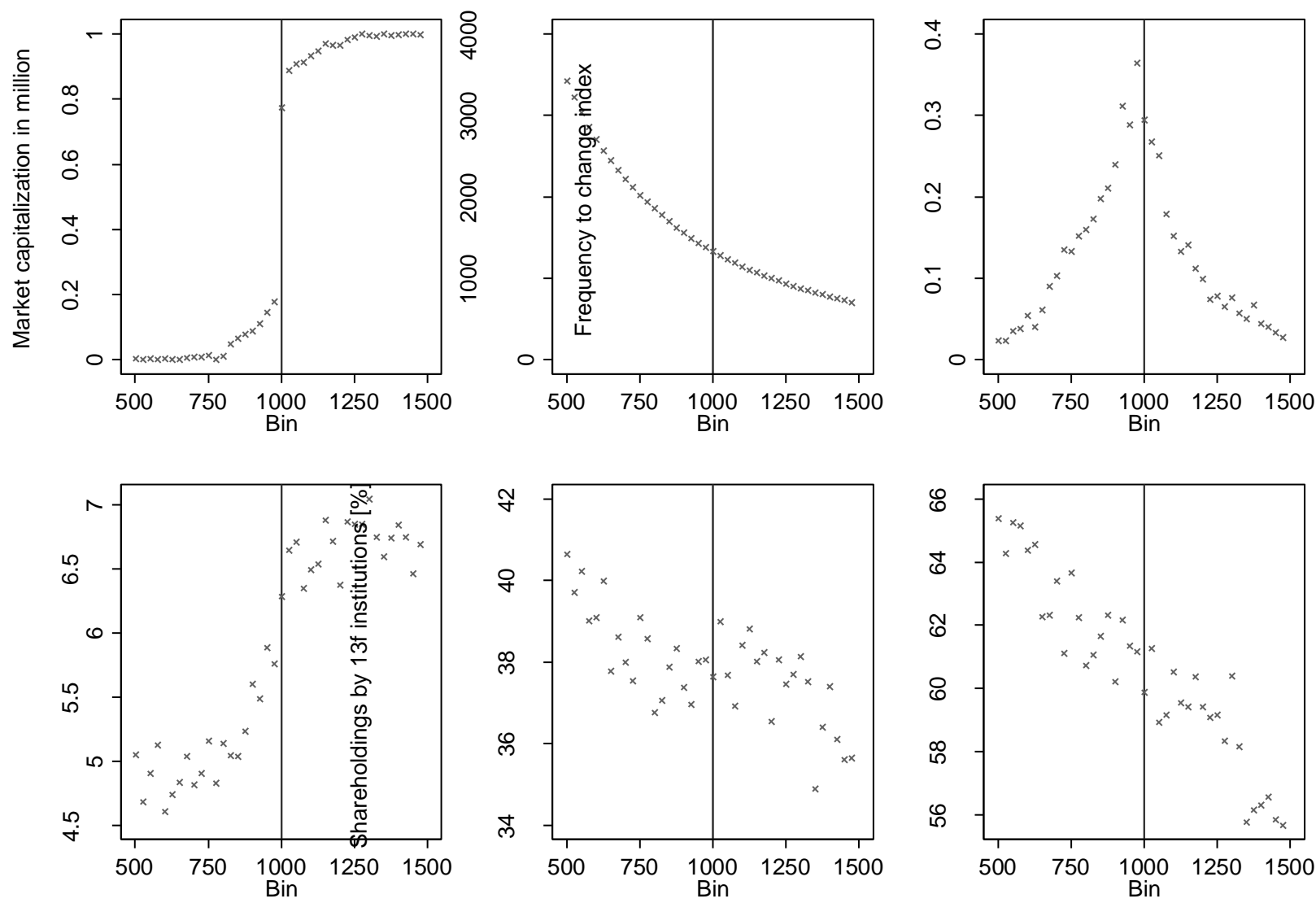

Fig. 3. Russell index assignment and passive institutional ownership, 1992-2010. The figure shows six graphs that support the validity of our empirical approach. The top left panel shows the fraction of firms in the Russell 2000 index, the top middle panel shows the (raw) market capitalization around the index threshold, and the top right panel shows the index switching probability. The three panels at the bottom show shareholdings of passive Russell 1000 and Russell 2000 investors combined (left panel), quasi-index tracking institutional investors (QIX) according to Bushee's (2001) classification (middle panel), and all institutional investors that file Form $13 \mathrm{f}$ (right panel). Stocks to the left of the vertical index threshold line should be members of the Russell 1000, and stocks to the right of the line are members of the Russell 2000. The sample period is 1992 to 2010. Bin size is 25 stocks. 
Table 1

Variable definitions.

The table contains the definition and data source for key variables used in the paper.

Variable

Definition

\section{Firm variables}

Market cap ${ }_{t-1}$

Return $_{t}$

$\mathrm{ROA}_{t}$

Raw Market cap

Rank $_{t}$

$\Delta$ Assets

Industry fixed effects

Passive institutional investors Sum of holdings by Russell 1000 and Russell 2000 mutual funds and ETFs, in \%

$\Delta$ Passive institutional investors The $\%$ change in shareholdings of passive funds from the fourth quarter in $t-1$

\section{CEO positions}

$\triangle$ Chairman

$\triangle$ President

\section{Board characteristics}

$\triangle$ Board independence

New indep. board member/ board size

\section{Shareholder Proposals}

G-index proposal

Number G-index proposals

\section{Acquisitions}

Target public

Target private

Deal consideration

Hostile deal

Competed deal

Same industry

Relative size to the third quarter in $t$.

Market capitalization $(\$ \mathrm{M}), \mathrm{csho}_{t-1} \mathrm{x}$ prcc_f $\mathrm{f}_{t-1}$

Monthly CRSP return aggregated over calendar year in $\%, \prod_{i=1}^{12}\left(1+r_{i}\right)-1$

ib / $\left(0.5 \times\left(a_{t}+a_{t-1}\right)\right) \times 100$

Estimate of market capitalization used by Russell to assign index membership

Rank of index constituents based on raw market capitalization in May $t$

$1-1000=$ Russell 1000 index, $1001-3000=$ Russell 2000 index

$\left(\ln \left(\mathrm{at}_{t}\right)-\ln \left(\mathrm{at}_{t-1}\right)\right) \times 100$

Fama French (48) industry dummies

$\mathrm{I}_{\mathrm{CEO} \& C h a i r m a n ; t}-\mathrm{I}_{\mathrm{CEO} \& C h a i r m a n ; t-1}$, in \%

$\mathrm{I}_{\mathrm{CEO} \& \text { President } t}-\mathrm{I}_{\mathrm{CEO} \& \text { President } ;-1-1}$, in $\%$

Change of board independence, in \%

Number of new independent board members / board size, in \%

Indicator variable equal to one if G-index proposal sponsored by shareholder, $\mathrm{x} 100$

Number of proposals sponsored by shareholder, x100

All proposals are collected at meeting dates between September ${ }_{t}$ and August ${ }_{t+1}$

Target is publicly listed (TargetPublicStatus = "Public")

Target is private (TargetPublicStatus = "Priv.")

Percentage of payment in shares

Attitude equals "Hostile"

A competing bidder exists (CompetingBidder)

Target and acquirer share the first two digits of their primary SIC code

Value of transaction over market capitalization of buyer, measured

11 days prior to announcement, in \%

All acquisitions are collected between July $t$ and June $t+1$
Source

Compustat

CRSP

Compustat

See Appendix A

Russell Investments

\& Appendix A

Compustat

K. French's website

Antti Petajisto's website

\& Thomson Reuters s12

\section{ExecuComp}

ExecuComp

RiskMetrics/IRRC

RiskMetrics/IRRC

RiskMetrics/IRRC

RiskMetrics/IRRC

SDC

SDC

SDC

SDC

SDC

SDC

SDC \& CRSP

Kenneth French's website http://mba.tuck.dartmouth.edu/pages/faculty/ken.french/data library.html

Antti Petajisto's website http://petajisto.net/data.html 
Table 2

Summary statistics.

The table shows means, medians, standard deviations, and number of observations for key variables. The number of observations varies because of data availability. The variable definitions and data sources are given in Table 1.

\begin{tabular}{|c|c|c|c|c|}
\hline Variable & Mean & Median & SD & $\mathrm{N}$ \\
\hline \multicolumn{5}{|l|}{ Index variables, ownership, and firm characteristics } \\
\hline Raw market cap. $(\$ \mathrm{M})$ & 3093 & 665 & 8131 & 56716 \\
\hline Index weight & 0.06 & 0.04 & 0.08 & 56716 \\
\hline Passive institutional investors & 5.47 & 4.07 & 4.98 & 56065 \\
\hline$\Delta$ Passive institutional investors & 0.28 & 0.23 & 3.30 & 44623 \\
\hline ROA & 1.80 & 3.83 & 14.44 & 51127 \\
\hline$\Delta$ Assets & 13.51 & 8.05 & 28.28 & 50915 \\
\hline \multicolumn{5}{|l|}{ CEO positions } \\
\hline CEO is chairman & 58.30 & 100.00 & 49.31 & 28382 \\
\hline CEO is president & 53.70 & 100.00 & 49.86 & 28382 \\
\hline$\triangle \mathrm{CEO}$ is chairman & 2.02 & 0.00 & 35.04 & 25504 \\
\hline$\Delta \mathrm{CEO}$ is president & 2.68 & 0.00 & 36.91 & 25504 \\
\hline \multicolumn{5}{|l|}{ Board characteristics } \\
\hline Board independence & 67.71 & 71.43 & 17.68 & 21674 \\
\hline$\Delta$ Board independence & 1.56 & 0.00 & 8.41 & 17944 \\
\hline New indep. board member/ board size & 7.94 & 0.00 & 10.21 & 18631 \\
\hline New indep. board member & 0.78 & 0.00 & 1.02 & 18631 \\
\hline \multicolumn{5}{|l|}{ Shareholder proposals } \\
\hline G-index proposal & 6.46 & 0.00 & 24.59 & 13991 \\
\hline Number G-index proposals & 7.92 & 0.00 & 33.40 & 13991 \\
\hline \multicolumn{5}{|l|}{ Deal characteristics } \\
\hline Target public & 0.25 & 0 & 0.43 & 9125 \\
\hline Target private & 0.42 & 0 & 0.49 & 9125 \\
\hline Deal consideration & 26.46 & 0 & 40.54 & 9125 \\
\hline Hostile deal & 0.003 & 0 & 0.05 & 9125 \\
\hline Competed deal & 0.010 & 0 & 0.10 & 9125 \\
\hline Relative size & 18.00 & 6.80 & 30.31 & 9125 \\
\hline Same industry & 0.58 & 1 & 0.49 & 9125 \\
\hline \multicolumn{5}{|l|}{ Announcement returns } \\
\hline Raw CAR $[-4,0]$ director appointment & 0.481 & 0.326 & 5.84 & 1991 \\
\hline CAPM CAR $[-4,0]$ director appointment & 0.264 & 0.069 & 4.98 & 1991 \\
\hline Fama French CAR $[-4,0]$ director appointment & 0.349 & 0.129 & 4.93 & 1991 \\
\hline Raw CAR $[-4,0]$ CEO power increase & -0.563 & 0.317 & 9.18 & 144 \\
\hline CAPM CAR $[-4,0]$ CEO power increase & -0.324 & -0.090 & 6.66 & 144 \\
\hline Fama French CAR $[-4,0]$ CEO power increase & -0.013 & -0.091 & 5.89 & 144 \\
\hline Raw CAR $[0,1]$ acquisition & 0.494 & 0.282 & 5.40 & 9125 \\
\hline CAPM CAR $[0,1]$ acquisition & 0.381 & 0.166 & 5.20 & 9125 \\
\hline Fama French CAR $[0,1]$ acquisition & 0.369 & 0.161 & 5.14 & 9125 \\
\hline
\end{tabular}




\section{Table 3}

Determinants of changes in passive institutional investors and relevancy condition.

The table presents results from OLS regression of determinants of percentage changes of passive institutional investor ownership on explanatory variables and our set of instruments. Instruments are indicator variables equal to one if a stock switches from the Russell 1000 to the Russell 2000 (I1000 $_{t-1}$-> $\mathrm{I} 2000_{t}$ ) or the Russell 2000 to the Russell $1000\left(\mathrm{I} 2000_{t-1}>\mathrm{I} 1000_{t}\right)$ at the annual Russell index reconstitution in May as well as the change in index rank. Control variables are defined in Table 1. Column 1 shows a regression of changes in passive ownership on the set of instruments for our entire sample period (1993 to 2010). Column 2 shows a regression for the period 2004-2010. Column 3 shows a regression for the entire sample period, but only includes firms that have complete coverage in ExecuComp. Column 3 also includes a set of control variables that is representative for all tests. All regressions include Fama and French (48) industry dummies as well as year-fixed effects. Standard errors are robust to heteroskedasticity and clustered by firm. $T$-statistics are displayed below the coefficients. Asterisks indicate significance at the $10 \%(*), 5 \%(* *)$, and $1 \%(* * *)$ level, respectively.

\begin{tabular}{|c|c|c|c|}
\hline & (1) & (2) & (3) \\
\hline \multirow[t]{2}{*}{$\mathrm{I} 1000_{t-1} \rightarrow \mathrm{I}_{2000_{t}}$} & $0.21 *$ & $1.73 * * *$ & $0.47 * * *$ \\
\hline & (1.96) & (7.99) & $(2.95)$ \\
\hline \multirow[t]{2}{*}{$\mathrm{I} 2000_{t-1} \rightarrow \mathrm{I} 1000_{t}$} & $-1.05 * * *$ & $-2.63 * * *$ & $-1.36 * * *$ \\
\hline & $(-9.60)$ & $(-13.17)$ & $(-8.73)$ \\
\hline \multirow[t]{2}{*}{$\left(\operatorname{Rank}_{t}-\operatorname{rank}_{t-1}\right) / 100$} & $-0.16^{* * *}$ & $-0.12 * * *$ & $-0.17 * * *$ \\
\hline & $(-28.32)$ & $(-11.34)$ & $(-13.25)$ \\
\hline Return $_{t}$ & & & $\begin{array}{l}0.01 \text { *** } \\
(10.60)\end{array}$ \\
\hline Return $_{t-1}$ & & & $\begin{array}{l}-0.00 * * * \\
(-3.32)\end{array}$ \\
\hline \multirow[t]{2}{*}{ ROA } & & & -0.00 \\
\hline & & & $(-0.76)$ \\
\hline \multirow[t]{2}{*}{$\Delta$ Assets } & & & 0.00 \\
\hline & & & $(0.69)$ \\
\hline \multirow[t]{2}{*}{ Market cap $_{t-1} / 1000$} & & & $-0.02 * * *$ \\
\hline & & & $(-10.12)$ \\
\hline$N$ & 44,623 & 18,162 & 22,422 \\
\hline Adj. $R^{2}$ & 0.081 & 0.119 & 0.097 \\
\hline Industry dummies & Yes & Yes & Yes \\
\hline Year dummies & Yes & Yes & Yes \\
\hline
\end{tabular}


Table 4

CEO power and passive institutional investors.

The table presents results from OLS and 2SLS instrumental variable regressions of the likelihood to gain or lose the position of the chairman of the board ( $\Delta$ Chairman, Columns 1 and 2 ) and president of the company ( $\Delta$ President, Columns 3 and 4 ) on changes in holdings by passive institutional investors. Control variables are defined in Table 1. The sample period includes fiscal years from 1994 to 2010. Columns 1 and 3 show OLS regressions, and Columns 2 and 4 show instrumental variable regressions. Column 5 shows the results of the first stage of the instrumental variable regressions. The regressions include, but do not report, year dummies as well as Fama-French (48) industry dummies. Standard errors are robust to heteroskedasticity and clustered by firm. T/Z-statistics are displayed below the coefficients. Asterisks indicate statistical significance at the 10\% (*), 5\% (**), and 1\%(***) level, respectively.

\begin{tabular}{|c|c|c|c|c|c|}
\hline & \multicolumn{2}{|c|}{$\Delta$ Chairman } & \multicolumn{2}{|c|}{$\Delta$ President } & \multirow[b]{2}{*}{$\begin{array}{c}1^{\text {st }} \text { Stage } \\
(5)\end{array}$} \\
\hline & $\begin{array}{l}\text { OLS } \\
(1)\end{array}$ & $\begin{array}{l}\text { IV } \\
(2)\end{array}$ & $\begin{array}{l}\text { OLS } \\
(3)\end{array}$ & $\begin{array}{l}\text { IV } \\
\text { (4) }\end{array}$ & \\
\hline$\Delta$ Passive institutional & 0.03 & $1.70 * * *$ & $0.14^{*}$ & $1.38 * *$ & \\
\hline investors & $(0.44)$ & $(2.63)$ & $(1.74)$ & $(2.05)$ & \\
\hline Return $_{t}$ & $\begin{array}{l}0.02 * * * \\
(3.59)\end{array}$ & $\begin{array}{c}0.01 \\
(0.92)\end{array}$ & $\begin{array}{l}0.01 * \\
(1.84)\end{array}$ & $\begin{array}{c}0.00 \\
(0.13)\end{array}$ & $\begin{array}{l}0.01 * * * \\
(10.07)\end{array}$ \\
\hline Return $_{t-1}$ & $\begin{array}{l}0.02 * * * \\
(3.88)\end{array}$ & $\begin{array}{c}0.02 * * * \\
(3.13)\end{array}$ & $\begin{array}{l}0.01 * * \\
(1.99)\end{array}$ & $\begin{array}{c}0.01 \\
(1.53)\end{array}$ & $\begin{array}{l}-0.00 * * \\
(-2.18)\end{array}$ \\
\hline$\Delta$ Assets & $\begin{array}{l}0.04 * * * \\
(3.38)\end{array}$ & $\begin{array}{c}0.04 * * * \\
(3.03)\end{array}$ & $\begin{array}{c}0.02 \\
(1.45)\end{array}$ & $\begin{array}{c}0.01 \\
(1.17)\end{array}$ & $\begin{array}{c}0.00 \\
(0.29)\end{array}$ \\
\hline Market cap cal $_{t-1} 1000$ & $\begin{array}{l}-0.04 * * * \\
(-2.90)\end{array}$ & $\begin{array}{c}-0.01 \\
(-0.73)\end{array}$ & $\begin{array}{l}-0.06^{* * *} \\
(-4.19)\end{array}$ & $\begin{array}{l}-0.04 * * \\
(-2.25)\end{array}$ & $\begin{array}{l}-0.02 * * * \\
(-12.67)\end{array}$ \\
\hline $\mathrm{I}_{1000_{t-1}} \rightarrow \mathrm{I} 2000_{t}$ & & & & & $\begin{array}{c}0.57 * * * \\
(3.58)\end{array}$ \\
\hline $\mathrm{I}^{2000}{ }_{t-1} \rightarrow \mathrm{I} 1000_{t}$ & & & & & $\begin{array}{c}-1.37 * * * \\
(-9.12)\end{array}$ \\
\hline$\left(\operatorname{Rank}_{t}-\operatorname{rank}_{t-1}\right) / 100$ & & & & & $\begin{array}{l}-0.16^{* * *} \\
(-13.03)\end{array}$ \\
\hline$N$ & 23,412 & 23,412 & 23,412 & 23,412 & 23,412 \\
\hline $\operatorname{Adj} . R^{2}$ & 0.008 & -0.017 & 0.003 & -0.009 & 0.093 \\
\hline Kleibergen-Paap $F$-sta & & & & & 76.18 \\
\hline
\end{tabular}


Table 5

Changes to the board of directors and passive institutional investors.

The table presents results from OLS and 2SLS regressions of changes in board independence and the fraction of new independent director appointments on changes in holdings by passive institutional investors. Columns 1 and 2 show OLS and IV regression results of the changes in board independence, defined as the number of independent directors divided by board size. Columns 4 and 5 show OLS and IV regression results of the number of new independent board members divided by board size. Columns 3 and 6 show the first stage regression results of the 2SLS instrumental variable regressions. Control variables are defined in Table 1. The sample period includes fiscal years from 1996 to 2010. The regressions include, but do not report, year dummies as well as Fama-French (48) industry dummies. Standard errors are robust to heteroskedasticity and clustered by firm. $T / Z$-statistics are displayed below the coefficients. Asterisks indicate statistical significance at the $10 \%(*), 5 \%(* *)$, and $1 \%(* * *)$ level, respectively.

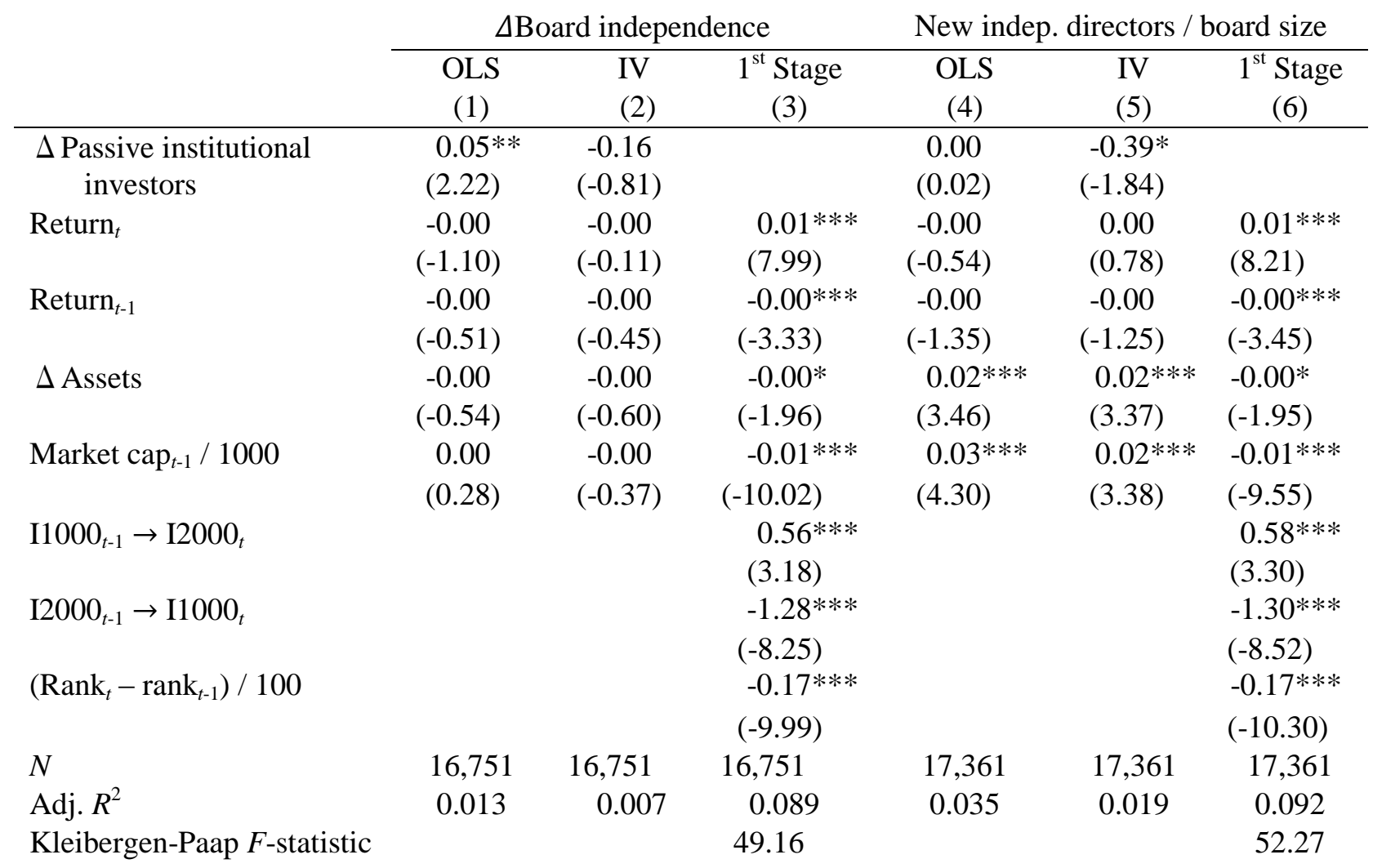




\section{Table 6}

Shareholder reactions to new board appointments.

Panel A shows OLS and IV estimation results of regressions of the announcement return of appointing a new independent director to the board on changes in holdings by passive institutional investors and control variables. Columns 1 to 3 show results for cumulative raw returns. Column 4 shows results for cumulative market-model-adjusted returns, and Column 5 shows results for cumulative Fama-French four-factor model-adjusted returns. We calculate the cumulative abnormal return over the event window $[-4,0]$, where day 0 is the filing date of the Form 8-K that discloses the director appointment. Column 6 shows first stage regression results of the 2SLS instrumental variable regressions of Columns 3-5. Control variables are as defined in Table 1. The regressions include, but do not report, year dummies as well as Fama-French (48) industry dummies. Standard errors are robust to heteroskedasticity and clustered by firm. $T / Z$-statistics are displayed below the coefficients. Asterisks indicate significance at the $10 \%(*), 5 \%(* *)$, and $1 \%(* * *)$ level, respectively. The Kleibergen-Paap $F$-statistic is from the (unreported) first stage of each of the IV regressions. Panel B shows results only for firms that switch the Russell index. The panel reports cumulative Fama-French four-factor model abnormal announcement returns to director appointments in the two years before the switch, and compares them with the announcement returns of director appointments in the year of and the year after the index reassignment. The sample includes announcements between 2004 and 2010.

Panel A: Announcement returns of new independent directors (CAR[-4,0])

\begin{tabular}{|c|c|c|c|c|c|c|}
\hline $\begin{array}{l}\text { Benchmark model } \\
\text { Regression type }\end{array}$ & $\begin{array}{l}\text { Raw } \\
\text { OLS } \\
(1)\end{array}$ & $\begin{array}{l}\text { Raw } \\
\text { IV } \\
(2)\end{array}$ & $\begin{array}{l}\text { Raw } \\
\text { IV } \\
\text { (3) }\end{array}$ & $\begin{array}{l}\text { CAPM } \\
\text { IV } \\
(4)\end{array}$ & $\begin{array}{l}\text { FF } \\
\text { IV } \\
(5)\end{array}$ & $\begin{array}{l}1 \mathrm{st} \\
(6)\end{array}$ \\
\hline$\Delta$ Passive institutional investors & $\begin{array}{l}-0.10 * * \\
(-2.34)\end{array}$ & $\begin{array}{l}-0.51 * * \\
(-2.00)\end{array}$ & $\begin{array}{l}-0.65 * * \\
(-2.02)\end{array}$ & $\begin{array}{l}-0.69 * * \\
(-2.36)\end{array}$ & $\begin{array}{l}-0.66 * * \\
(-2.44)\end{array}$ & \\
\hline Number of directors appointed & $\begin{array}{l}0.74 * * \\
(2.34)\end{array}$ & $\begin{array}{l}0.67 * * \\
(2.12)\end{array}$ & $\begin{array}{l}0.53 \\
(1.51)\end{array}$ & $\begin{array}{l}0.41 \\
(1.43)\end{array}$ & $\begin{array}{l}0.39 \\
(1.33)\end{array}$ & $\begin{array}{l}-0.22 \\
(-1.18)\end{array}$ \\
\hline Appointment between January and June? & $\begin{array}{l}-0.08 \\
(-0.30)\end{array}$ & $\begin{array}{l}-0.16 \\
(-0.58)\end{array}$ & $\begin{array}{l}0.01 \\
(0.04)\end{array}$ & $\begin{array}{l}-0.02 \\
(-0.08)\end{array}$ & $\begin{array}{l}-0.27 \\
(-1.06)\end{array}$ & $\begin{array}{l}-0.26 \\
(-1.61)\end{array}$ \\
\hline$\Delta$ Board size & & & $\begin{array}{l}0.12 \\
(0.89)\end{array}$ & $\begin{array}{l}0.09 \\
(0.79)\end{array}$ & $\begin{array}{l}0.05 \\
(0.45)\end{array}$ & $\begin{array}{l}0.11 \\
(1.51)\end{array}$ \\
\hline Return $_{t}$ & $\begin{array}{l}0.01 * * \\
(2.12)\end{array}$ & $\begin{array}{l}0.01 * * \\
(2.49)\end{array}$ & $\begin{array}{l}0.02 * * * \\
(2.95)\end{array}$ & $\begin{array}{l}0.01 * * * \\
(2.52)\end{array}$ & $\begin{array}{l}0.01 * * * \\
(2.78)\end{array}$ & $\begin{array}{l}0.01 * * * \\
(2.62)\end{array}$ \\
\hline Return $_{t-1}$ & $\begin{array}{l}-0.00 \\
(-0.79)\end{array}$ & $\begin{array}{l}-0.00 \\
(-0.90)\end{array}$ & $\begin{array}{l}-0.01 \\
(-1.31)\end{array}$ & $\begin{array}{l}-0.00 \\
(-0.71)\end{array}$ & $\begin{array}{l}-0.00 \\
(-1.10)\end{array}$ & $\begin{array}{l}-0.00 \\
(-1.25)\end{array}$ \\
\hline$\Delta$ Assets & $\begin{array}{l}-0.00 \\
(-0.21)\end{array}$ & $\begin{array}{l}-0.00 \\
(-0.30)\end{array}$ & $\begin{array}{l}-0.00 \\
(-0.15)\end{array}$ & $\begin{array}{l}-0.00 \\
(-0.16)\end{array}$ & $\begin{array}{l}-0.00 \\
(-0.28)\end{array}$ & $\begin{array}{l}-0.00 \\
(-0.89)\end{array}$ \\
\hline Market cap ${ }_{t-1} / 1000$ & $\begin{array}{l}-0.00 \\
(-0.34)\end{array}$ & $\begin{array}{l}-0.00 \\
(-0.59)\end{array}$ & $\begin{array}{l}-0.00 \\
(-0.22)\end{array}$ & $\begin{array}{l}-0.00 \\
(-0.24)\end{array}$ & $\begin{array}{l}-0.01 \\
(-0.71)\end{array}$ & $\begin{array}{l}-0.00 \\
(-0.91)\end{array}$ \\
\hline $\begin{array}{l}\mathrm{I} 1000_{t-1} \rightarrow \mathrm{I}^{2000} t \\
\mathrm{I} 2000_{t} \rightarrow \mathrm{I} 1000\end{array}$ & & & & & & $\begin{array}{l}2.20 * * * \\
(2.84) \\
-2.52 * * *\end{array}$ \\
\hline$\left(\operatorname{Rank}_{t}-\operatorname{rank}_{t-1}\right) / 100$ & & & & & & $\begin{array}{l}(-4.44) \\
-0.09 \\
(-1.34)\end{array}$ \\
\hline$N$ & 1,991 & 1,991 & 1,794 & 1,794 & 1,794 & 1,794 \\
\hline Adj. $R^{2}$ & 0.007 & -0.073 & -0.108 & -0.173 & -0.166 & -0.001 \\
\hline Kleibergen-Paap $F$-statistic & & 11.58 & 9.07 & 9.07 & 9.07 & \\
\hline
\end{tabular}


Panel B: Announcement returns of new independent director appointments before and after index switch

\begin{tabular}{lcccc} 
& \multicolumn{5}{c}{ Fama-French CAR[-4, 0] } \\
\cline { 2 - 5 } & $\begin{array}{l}\text { Russell } \\
\text { mean }\end{array}$ & $\begin{array}{c}\text { Russell 2000 } \\
\text { median }\end{array}$ & $\begin{array}{l}\text { Russell } 2000 \\
\text { mean }\end{array}$ & $\begin{array}{c}\text {-> Russell } 1000 \\
\text { median }\end{array}$ \\
\hline $\begin{array}{l}\text { Pre-switch } \\
t \text {-value }\end{array}$ & 0.847 & 0.678 & -0.130 & -0.417 \\
Post-switch & 1.40 & & -0.26 & 0.299 \\
$t$-value & -0.793 & -0.942 & 1.073 & \\
$p$-value for difference & -1.14 & & 1.92 & 0.090 \\
$N$ & 0.081 & 0.078 & 0.113 & 196
\end{tabular}




\section{Table 7}

Changes to the number of shareholder proposals and passive institutional investors.

The table presents results from OLS and 2SLS instrumental variable regressions of changes in the number of shareholder proposals submitted to the annual meeting on changes in holdings by passive institutional investors and control variables. Columns 1 and 2 show OLS and IV regression results of the changes in the number of submitted proposals. Column 3 shows first stage regression results of the 2SLS instrumental variable regression. Control variables are defined in Table 1. The sample period includes years from 1997 to 2005 . The regressions include, but do not report, year dummies as well as FamaFrench (48) industry dummies. Standard errors are robust to heteroskedasticity and clustered by firm. $T / Z$ statistics are displayed below the coefficients. Asterisks indicate statistical significance at the 10\% (*), $5 \%(* *)$, and $1 \%(* * *)$ level, respectively.

Change in number of shareholder proposals [\%]

\begin{tabular}{|c|c|c|c|}
\hline & \multicolumn{3}{|c|}{ 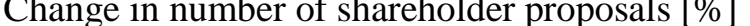 } \\
\hline & $\begin{array}{l}\text { OLS } \\
(1)\end{array}$ & $\begin{array}{l}\text { IV } \\
(2)\end{array}$ & $\begin{array}{l}\text { First stage } \\
\text { (3) }\end{array}$ \\
\hline \multirow{2}{*}{$\begin{array}{l}\Delta \text { Passive institutional } \\
\text { investors }\end{array}$} & -0.10 & $-1.14^{*}$ & \\
\hline & $(-1.00)$ & $(-1.82)$ & \\
\hline \multirow[t]{2}{*}{ Return $_{t}$} & -0.01 & 0.00 & $0.01 * * *$ \\
\hline & $(-0.95)$ & $(0.38)$ & $(7.67)$ \\
\hline \multirow[t]{2}{*}{ Return $_{t-1}$} & -0.01 & -0.00 & -0.00 \\
\hline & $(-0.88)$ & $(-0.49)$ & $(-1.56)$ \\
\hline \multirow[t]{2}{*}{ ROA } & 0.02 & 0.02 & $-0.01 * *$ \\
\hline & $(0.72)$ & $(0.63)$ & $(-2.05)$ \\
\hline \multirow[t]{2}{*}{$\Delta$ Assets } & $0.04 * *$ & $0.04 * *$ & -0.00 \\
\hline & $(2.43)$ & $(2.42)$ & $(-0.73)$ \\
\hline \multirow[t]{2}{*}{ Market cap ${ }_{t-1} / 1000$} & $-0.03 *$ & $-0.05 * *$ & $-0.02 * * *$ \\
\hline & $(-1.66)$ & $(-2.30)$ & $(-9.84)$ \\
\hline $\mathrm{I}_{1000_{t-1}} \rightarrow{\mathrm{I} 2000_{t}}$ & & & $\begin{array}{l}0.46^{* *} \\
(2.33)\end{array}$ \\
\hline $\mathrm{I} 2000_{t-1} \rightarrow{\mathrm{I} 1000_{t}}$ & & & $\begin{array}{l}-1.18^{* * * *} \\
(-7.16)\end{array}$ \\
\hline$\left(\operatorname{Rank}_{t}-\operatorname{rank}_{t-1}\right) / 100$ & & & $\begin{array}{l}-0.18^{* * *} \\
(-8.78)\end{array}$ \\
\hline$N$ & 10,949 & 10,949 & 10,949 \\
\hline $\operatorname{Adj} . R^{2}$ & 0.001 & -0.015 & 0.028 \\
\hline Kleibergen-Paap $F$-sta & & & 36.58 \\
\hline
\end{tabular}




\section{Table 8}

Shareholder reactions to acquisition announcements.

Panel A shows OLS and IV estimation results of regressions of the cumulative announcement return of announcing an acquisition on changes in holdings by passive institutional investors and control variables. Cumulative abnormal returns are calculated over the event window $[0,1]$, where day 0 is the announcement date of the acquisition. Cumulative returns are calculated using raw returns (Columns 13), market-model-adjusted returns (Column 4), and Fama-French four-factor model-adjusted returns (Column 5). Column 6 shows first stage regression results of the 2SLS instrumental variable regression of Columns 3-5. Control variables are as defined in Table 1. The regressions include, but do not report, year dummies as well as Fama-French (48) industry dummies. Standard errors are robust to heteroskedasticity and clustered by firm. T/Z-statistics are displayed below the coefficients. Asterisks indicate significance at the $10 \%(*), 5 \%(* *)$, and $1 \%(* * *)$ level, respectively. The Kleibergen-Paap $F$-statistic is from the (unreported) first stage of each of the IV regressions. Panel B shows results only for firms that switch the index. The panel reports Fama-French four-factor cumulative abnormal announcement returns to acquisitions in the two years before the switch, and compares them with the announcement returns of acquisitions in the year of and the year after the index reassignment. Panel A includes announcements from 1993 to 2010, while Panel B covers 1992-2010. 
Panel A: Announcement returns to acquisition announcements (CAR[0, 1])

\begin{tabular}{|c|c|c|c|c|c|c|}
\hline \multirow[t]{2}{*}{$\begin{array}{l}\text { Benchmark model } \\
\text { Regression type } \\
\end{array}$} & $\begin{array}{l}\text { Raw } \\
\text { OLS }\end{array}$ & $\begin{array}{l}\text { Raw } \\
\text { IV }\end{array}$ & $\begin{array}{l}\text { Raw } \\
\text { IV }\end{array}$ & $\begin{array}{l}\text { CAPM } \\
\text { IV }\end{array}$ & $\begin{array}{l}\text { FF } \\
\text { IV }\end{array}$ & $1 \mathrm{st}$ \\
\hline & (1) & (2) & (3) & (4) & (5) & (6) \\
\hline$\Delta$ Passive institutional & -0.01 & $-0.35 * *$ & $-0.38 * *$ & $-0.32 * *$ & $-0.32 * *$ & \\
\hline $\begin{array}{l}\text { 1nvestors } \\
\text { Taroet nublic }\end{array}$ & $(-0.61)$ & $(-2.10)$ & $(-2.31)$ & $(-2.08)$ & $(-2.10)$ & \\
\hline Target public & $\begin{array}{l}-2.21 * * * \\
(-11.50)\end{array}$ & & $\begin{array}{l}-2.23 * * * \\
(-11.32)\end{array}$ & $\begin{array}{l}-2.33 * * * \\
(-12.37)\end{array}$ & $\begin{array}{l}-2.26 * * * \\
(-12.12)\end{array}$ & $\begin{array}{l}-0.06 \\
(-0.52)\end{array}$ \\
\hline Target private & $\begin{array}{l}-0.39 * * * \\
(-2.92)\end{array}$ & & $\begin{array}{l}-0.39 * * * \\
(-2.83)\end{array}$ & $\begin{array}{l}-0.35 * * * \\
(-2.71)\end{array}$ & $\begin{array}{l}-0.31 * * \\
(-2.39)\end{array}$ & $\begin{array}{l}-0.01 \\
(-0.18)\end{array}$ \\
\hline Deal consideration & $\begin{array}{l}-0.01 * * * \\
(-3.90)\end{array}$ & & $\begin{array}{l}-0.01 * * * \\
(-3.46)\end{array}$ & $\begin{array}{l}-0.01 * * * \\
(-3.65)\end{array}$ & $\begin{array}{l}-0.01 * * * \\
(-3.75)\end{array}$ & $\begin{array}{l}0.00 * \\
(1.81)\end{array}$ \\
\hline Hostile deal & 0.57 & & 0.78 & 0.75 & 0.77 & 0.56 \\
\hline & $(0.57)$ & & $(0.69)$ & $(0.67)$ & $(0.69)$ & $(0.83)$ \\
\hline Competed deal & -0.35 & & -0.37 & -0.14 & -0.24 & -0.03 \\
\hline & $(-0.62)$ & & $(-0.66)$ & $(-0.25)$ & $(-0.43)$ & $(-0.08)$ \\
\hline Same industry & $\begin{array}{c}0.16 \\
(1.17)\end{array}$ & & $\begin{array}{c}0.19 \\
(1.42)\end{array}$ & $\begin{array}{l}0.29 * * \\
(2.20)\end{array}$ & $\begin{array}{l}0.27 * * \\
(2.10)\end{array}$ & $\begin{array}{c}0.11 \\
(1.32)\end{array}$ \\
\hline Relative size & 0.00 & & 0.00 & 0.00 & 0.00 & 0.00 \\
\hline & $(1.50)$ & & $(1.56)$ & $(1.59)$ & $(1.34)$ & $(1.01)$ \\
\hline Return $_{t}$ & $0.01 * * *$ & $0.01 * * *$ & $0.01 * * *$ & $0.01 * * *$ & $0.01 * * *$ & $0.01 * * *$ \\
\hline $\operatorname{Return}_{t-1}$ & $\begin{array}{c}(3.44) \\
0.00\end{array}$ & $\begin{array}{c}(3.55) \\
0.00\end{array}$ & $\begin{array}{r}(4.05) \\
0.00 *\end{array}$ & $\begin{array}{l}(4.25) \\
0.00 *\end{array}$ & $\begin{array}{c}(3.66) \\
0.00\end{array}$ & $\begin{array}{l}(4.82) \\
-0.00\end{array}$ \\
\hline$\Delta$ Assets & $\begin{array}{c}(1.17) \\
-0.00 \\
(-0.19)\end{array}$ & $\begin{array}{c}(1.42) \\
0.00 \\
(0.27)\end{array}$ & $\begin{array}{c}(1.72) \\
0.00 \\
(0.56)\end{array}$ & $\begin{array}{l}(1.75) \\
0.00 \\
(0.63)\end{array}$ & $\begin{array}{c}(1.48) \\
0.00 \\
(0.55)\end{array}$ & $\begin{array}{c}(-0.50) \\
0.00 \\
(1.46)\end{array}$ \\
\hline Market cap $t-1 / 1000$ & $\begin{array}{l}-0.01 * * \\
(-2.39)\end{array}$ & $\begin{array}{l}-0.04 * * * \\
(-5.56)\end{array}$ & $\begin{array}{l}-0.02 * * * \\
(-3.10)\end{array}$ & $\begin{array}{l}-0.01 * * \\
(-2.12)\end{array}$ & $\begin{array}{l}-0.02 * * \\
(-2.30)\end{array}$ & $\begin{array}{l}-0.02 * * * \\
(-586)\end{array}$ \\
\hline $\mathrm{I}_{1000} t_{t-1} \rightarrow \mathrm{I}^{2} 000_{t}$ & & & & & & $\begin{array}{c}(-5.00) \\
0.05 \\
(0.13)\end{array}$ \\
\hline $\mathrm{I}_{2000} \rightarrow \mathrm{I}_{t-1} 000_{t}$ & & & & & & $\begin{array}{l}-1.21 * * * \\
(-4.09)\end{array}$ \\
\hline$\left(\operatorname{Rank}_{t}-\operatorname{rank}_{t-1}\right) / 100$ & & & & & & $\begin{array}{l}-0.16^{* * * *} \\
(-6.65)\end{array}$ \\
\hline$N$ & 9,125 & 9,125 & 9,125 & 9,125 & 9,125 & 9,125 \\
\hline $\begin{array}{l}\text { Adj. } R^{<} \\
\text {Kleibergen-Paap } F \text {-statistic }\end{array}$ & 0.048 & $\begin{array}{l}-0.043 \\
16.63\end{array}$ & $\begin{array}{l}-0.022 \\
16.93\end{array}$ & $\begin{array}{l}-0.008 \\
16.93\end{array}$ & $\begin{array}{l}-0.009 \\
16.93\end{array}$ & 0.043 \\
\hline
\end{tabular}

Panel B: Announcement returns to acquisition announcements before and after index switch (FamaFrench CAR $[0,1])$

\begin{tabular}{|c|c|c|c|c|}
\hline & \multicolumn{2}{|c|}{ Russell 1000 -> Russell 2000} & \multicolumn{2}{|c|}{ Russell 2000 -> Russell 1000} \\
\hline & mean & median & mean & median \\
\hline Pre-switch & 0.948 & 0.213 & -0.069 & 0.150 \\
\hline$t$-value & 2.87 & & -0.27 & \\
\hline Post-switch & -0.075 & -0.246 & 1.258 & 0.427 \\
\hline$t$-value & -0.25 & & 6.44 & \\
\hline$p$-value for differences & 0.027 & 0.014 & 0.000 & 0.006 \\
\hline$N$ & & & & \\
\hline
\end{tabular}

